\title{
EL IDEARIO EDUCATIVO CONSTITUCIONAL COMO LÍMITE A LAS LIBERTADES EDUCATIVAS ${ }^{1}$
}

\author{
PROF. DR. BENITO ALÁEZ CORRAL ${ }^{2}$
}

\begin{abstract}
RESUMO: Este artigo reconstrói, com a ajuda do direito internacional e do direito europeu comparado, o significado normativo do denominado "ideário educativo constitucional" do art. 27.2 da Constituição Espanhola, que estabelece a educação cívico-democrática como finalidade obrigatória da educação e, com isso, delimita as liberdades educacionais. Como exemplos disso são analisadas a possível inconstitucionalidade da educação diferenciada e a carência de amparo constitucional das opções pelo homeschooling ou pela objeção de consciência a aulas de educação democrática.

PALAVRAS-CHAVE: Direito Constitucional; Direitos Fundamentais; Direito à Educação; Liberdades Educacionais; Ideário Educativo Constitucional; Objeção de Consciência Escolar; Educação Diferenciada; Homeschooling.
\end{abstract}

ABSTRACT: This article reconstructs with the help of International Law and European Comparative Law the normative meaning of the so-called "constitutional aims of education", set by art. $27.2 \mathrm{Sp}$. Const., that establishes civic-democratic education as constitutional aim of education and therefore limits freedoms in teaching. As examples of this limitations are showed the possible unconstitutionality of single-sex educaton and the lack of constitutional protection of home-schooling and parental objection to Democratic Education Courses.

KEYWORDS: Constitutional Law; Fundamental Rights; Right to Education; Freedoms in Teaching; Constitutional Aims of Education; Parental Objection to Civic Education; Single-sex Schooling; Homeschooling.

RESUMEN: Este artículo reconstruye con la ayuda del derecho internacional y el derecho europeo comparado el significado normativo del denominado ideario educativo constitucional del art. 27.2 CE, que establece la educación cívico-democrática como fin obligatorio de la educación y, con ello, delimita las libertades educativas. Como ejemplos de ello se analizan la posible inconstitucionalidad de la educación diferenciada y la carencia de amparo constitucional de las opciones por el homeschooling o de la objeción de conciencia a la asignatura Educación para la ciudadanía.

PALABRAS CLAVE: Derecho Constitucional; Derechos Fundamentales; Derecho a la Educación; Libertades Educativas; Ideario Educativo Constitucional; Objeción de Conciencia Escolar; Educación Diferenciada; Homeschooling.

Artigo recebido em 10.10.2011. Artigo aceito para publicação em 20.12.2011 mediante convite. ${ }^{1}$ Artigo publicado originalmente na Espanha na Revista Europea de Derechos Fundamentales, $n^{\circ} 17,2011$.

${ }^{2}$ Professor da Universidad de Oviedo. benito@uniovi.es 
SUMÁRIO: Introdução; 1. O Direito à Educação e as Liberdades Educacionais: Um direito único e complexo; 2. Antecedentes do Ideário Educativo Constitucional; 3. Normatividade Jurídica do Ideário Educativo Constitucional; 4. Alguns Exemplos de Delimitação das Liberdades Educacionais à luz do Ideário Educativo Constitucional; Referências.

SUMMARY: Introduction; 1. Right to Education and Freedoms in Teaching: One single complex right; 2. Precedets of Constitutional Aims of Education in International Law and European Comparative Law; 3. Legal Effects of Constitutional Aims of Education; 4. Some Examples of Limitations Upon the Freedoms in Teaching Derived from the Constitutional Aims of Education; References.

SUMARIO: Introducción; 1. El Derecho a la Educación y las Libertades Educativas: Un único derecho complejo. 2. Antecedentes del Ideario Educativo Constitucional en el Derecho Internacional y en el Derecho Europeo Comparado; 3. Normatividad Jurídica del Ideario Educativo Constitucional; 4. Algunos Ejemplos de Delimitación de las Libertades Educativas a la luz del Ideario Educativo Constitucional; Referencias.

\section{INTRODUCCIÓN}

El pluralismo cultural -más el interno que el externo- existente en las sociedades contemporáneas ha puesto de relieve en los último tiempos, tanto a nivel nacional como a nivel europeo, la inevitable tensión que existe entre la pretensión de las familias de ejercer las libertades educativas de acuerdo con sus propios valores y convicciones morales o religiosas (art. 27.1, 3, 6 y 7 CE) y la subordinación de esas libertades a los intereses de la colectividad, que expresan las autoridades educativas a través de sus competencias constitucionales (art. 27.5 CE) ${ }^{3}$, sobre todo cuando dichos intereses consisten en la protección de unos valores liberal-democráticos no siempre coincidentes con los valores de las familias o de los individuos que las integran ${ }^{4}$. A ello se añaden, en mi opinión, como un tercer elemento en discordia, los derechos del educando menor de edad que, aunque en atención a su condición de sujeto en formación pueda ver limitada su capacidad para ejercer su libertad por sí mismo, no deja de ser el auténtico titular y beneficiario de las facultades en que se plasma el derecho a la educación $n^{5}$.

\footnotetext{
${ }^{3}$ Véanse, por ejemplo, los recursos en Dinamarca en los años setenta contra la obligatoriedad de la educación sexual (Caso Kjeldsen and others v. Denmark), la pretensión de educar en casa objetando el sistema escolar reglado que gotea desde los años ochenta hasta la actualidad (Casos Jiménez Merino v. Spain; Konrad and others v. Germany) o, por último, la objeción a cursar una materia de educación en valores cívico-democráticos (Caso Appel-Irgang v. Germany; o los recursos interpuestos en España contra Educación para la ciudadanía).

${ }^{4}$ Estos distintos planteamientos de intereses se corresponderían con lo que en el campo de la filosofía política aplicada a las teorías sobre la educación A. Gutmann, Democratic Education, Princeton University Press, New Jersey, 1999, pp. 19-47 denomina "Estado de las familias", "Estado de los individuos" o finalmente "Estado democrático" de la educación.

${ }^{5}$ Cfr. B. Aláez Corral, Minoría de Edad y Derechos Fundamentales, Tecnos, Madrid, 2003, pp. 198-208.
} 
En este sentido, recientes decisiones judiciales, como las cuatro Sentencias del Tribunal Supremo de 11 de febrero de 2009 (Sala $\left.3^{a}\right)^{6}$, confirmando la constitucionalidad de la asignatura obligatoria "Educación para la ciudadanía" y negando el derecho a objetarla por razones de conciencia, o la más reciente Sentencia del Tribunal Constitucional 133/2010, de 2 de diciembre, confirmando la constitucionalidad de la escolarización obligatoria de los menores y la inexistencia de una libertad educativa fundamental para practicar el homeschooling sobre la base de la necesidad de socialización democrática del menor, chocan con una difícil comprensión por parte de amplios sectores de la sociedad. Ello se debe, en buena medida, a la errónea comprensión social que existe sobre cuál es el alcance normativo constitucional del derecho a la educación del art. 27 CE y del papel fundamental que juega ésta en la construcción de una sociedad democrática, lo que llevó al constituyente a subordinarla al logro de unas finalidades constitucional-democráticas. Como trataré de poner de relieve en las páginas siguientes, nuestra Constitución democrática de 1978 ha fijado un criterio vinculante para el correcto desenvolvimiento de este complejo escenario de pretensiones contrapuestas: lo que el tristemente desparecido magistrado del Tribunal Constitucional, Francisco Tomás y Valiente, llamó "ideario educativo de la Constitución", es decir, una serie de finalidades constitucional-democráticas que operan como necesario principio inspirador (positivo) de todo el proceso educativo y como límite (negativo) de las libertades educativas. En efecto, el art. 27.2 CE dispone que "la educación tendrá por objeto el pleno desarrollo de la personalidad humana en el respeto a los principios democráticos de convivencia y a los derechos y libertades fundamentales". Dicho de forma sencilla: ni los Estados democráticos en general, ni la CE de 1978 en particular, son neutrales en materia educativa; parten de la necesidad de inculcar al individuo desde su más tierna infancia la cultura del Estado democrático de derecho y el respeto por los derechos humanos como único camino para el pleno desarrollo de la personalidad y la dignidad del educando menor, pues conciben la educación como el mejor mecanismo preventivo para la protección de la democracia.

Se trata de un planteamiento, como se verá, ya conocido por los instrumentos internacionales más importantes, que instan a la educación para los derechos humanos, pero que es relativamente novedoso en el derecho constitucional europeo ${ }^{7}$, pues, aunque las legislaciones educativas

\footnotetext{
${ }^{6}$ Resolviendo recursos contencioso-administrativos interpuestos contra Sentencias del Tribunal Superior de Justicia de Andalucía y Asturias. Siempre que se haga referencia a estas SSTS de 11 de febrero de 2009 (Sala $3^{a}$ ), la referencia será a la Sentencia sobre los recursos presentados en Asturias de la que fue ponente el Magistrado Pablo Lucas Murillo de la Cueva.

${ }^{7}$ No son equivalentes ni el art. 366 de la Constitución española de 1812 que ordenaba que en las escuelas se hiciese una breve exposición de las obligaciones cívicas tanto por su parquedad (se refiere sólo a las obligaciones no a los derechos ni a las reglas de convivencia democrática) como por la diferente concepción del pluralismo y la igualdad que tenía la constitución doceañista (confesionalidad del Estado desigualdad racial, económica y sexual), ni tampoco el
} 
de muchos de los países europeos atribuyen a la educación una función y unos fines semejantes a los que dispone nuestro precepto constitucional, son pocas las Constituciones nacionales que conocen expresamente previsiones parecidas a las del art. 27.2 $\mathrm{CE}^{8}$.

La idea matriz de este trabajo es que el ideario educativo constitucional del art. 27.2 CE opera como un límite al ejercicio de las libertades educativas, además de como un objetivo positivamente vinculante en la prestación del derecho a la educación. Para desarrollar esta idea, intentaré poner de manifiesto, en primer término, el carácter unitario de las libertades y derechos educativos que se contienen el art. $27 \mathrm{CE}$, como un único derecho fundamental de carácter complejo que es necesario interpretar armónicamente. A continuación, trataré de demostrar cómo el hilo conductor de esa unidad y armonía sistemática lo aporta precisamente el ideario educativo constitucional, que, a la luz de su contenido democrático, se presenta como un límite lato sensu (más bien una delimitación) del contenido constitucional de las distintas libertades educativas garantizadas por el art. $27 \mathrm{CE}$, lo cual se ve corroborado tanto por la jurisprudencia del Tribunal Europeo de Derechos Humanos (TEDH) como por las distintas experiencias del derecho constitucional comparado. $Y$ por último trataré de mostrar las implicaciones que ya se están deduciendo de esta tesis por los más altos tribunales de nuestro Estado en relación con el ejercicio de algunas libertades educativas, como por ejemplo, la pretensión de educar diferenciadamente por sexos, la pretensión de educar en casa (homeschooling) o la objeción a la asignatura "Educación para la ciudadanía".

\section{1.- EL DERECHO EDUCACIÓN Y LAS LIBERTADES EDUCATIVAS:} UN ÚNICO DERECHO COMPLEJO

Que el llamado genéricamente "derecho a la educación" del art. $27 \mathrm{CE}$ y su equivalente del art. 2 del Protocolo 1 al Convenio Europeo de Derechos Humanos (CEDH) en lugar de contener varios derechos y libertades educativas -derecho prestacional a la educación, libertad de enseñanza, derecho parental a la elección de la formación religiosa y moral para sus hijos que esté de acuerdo con sus convicciones, libertad de creación de centros docentes, etc...- han de ser entendidos como un solo derecho complejo, es una conclusión dogmático-iusfundamental a la que, de forma cada vez más clara, conducen tanto la jurisprudencia europea como la jurisprudencia constitucional española ${ }^{9}$. Ciertamente, ha existido una larga

art. 48 de la Constitución española de 1931, que únicamente preveía que la educación fuese laica y se inspirase en la solidaridad humana.

${ }^{8}$ Entre estas pocas, cabe citar el art. 14.5a) de la Const. de Austria, el art. 24.2 de la Const. de Bélgica, el art. 16.2 Const. de Grecia, y el art. el art. 73.2 Const. de Portugal, el incluso el art. 8 de la Carta del Medio Ambiente francesa (de rango Constitucional), así como algunas "Constituciones" de los Estados federados alemanes (v. gr. art. 7.2 de la Constitución de Nord-Rhein Westfalen).

${ }^{9}$ El TEDH (desde la Sentencia de 7 de diciembre de 1976, Caso Kjeldsen, Busk Madsen y Pedersen v. Denmark, F.J. 50.) y el Tribunal Constitucional español (desde la STC 86/1985, 
discusión doctrinal al respecto, que no es sino el trasunto de la tensión entre la primacía del derecho a la educación y la de la libertad de enseñanza ${ }^{10}$, y la cuestión está muy vinculada a la más genérica del concepto de derecho fundamental ${ }^{11}$. Ahora bien, sin pretender entrar en esta última cuestión en detalle, en mi opinión, se ha de partir de que el derecho a la educación constituye un único derecho fundamental complejo, compuesto por un diversas normas orientadas a garantizar su objeto, la recepción de una educación libre, plural y democrática, a través de técnicas normativas que constituyen su contenido, tan variadas como un derecho prestacional a una educación básica gratuita, la libertad de enseñanza y la libre creación de centros docentes o la garantía de la autonomía universitaria ${ }^{12}$.

En efecto, que el art. 27 CE sea mucho más profuso en el conjunto de mandatos, permisos y prohibiciones que el art. 2 del Protocolo $n^{\circ} 1 \mathrm{CEDH}$, en aras de garantizar con mayor precisión el derecho a la educación, no obsta a que las distintas normas iusfundamentales deducibles de sus enunciados, sean interpretadas de forma interdependiente entre sí, dirigidas a garantizar activa y pasivamente aquel espacio de libertad. Así, el art. 27.1 CE garantiza literalmente el derecho de todos a recibir una educación, aunque para el logro de este objetivo se garantice, al mismo tiempo, la libertad de enseñanza. Dicho con otras palabras, el objeto del derecho a la educación del art. $27 \mathrm{CE}$ está compuesto por una esfera vital que no consiste ni exclusivamente en ejercer la libertad de enseñanza, la libertad de creación de centros docentes o la elección parental de la formación religiosa y moral que esté de acuerdo con sus convicciones, ni tampoco exclusivamente en la facultad de exigir la prestación educativa, sino que todas estas esferas prestacionales y de libertad se encuentran en una

de 10 de julio, F.J. $3^{\circ}$.) han llegado hace tiempo a conclusiones semejantes en lo que se refiere a la necesidad de entender las distintas facultades que componen el derecho a la educación en libertad como una unidad, y nunca contrapuestas las unas con las otras, es decir, a la necesidad de reconstruir interpretativamente sus contenidos obligatorios en el sentido de una concordancia práctica entre los distintas facultades iusfundamentales.

${ }^{10}$ Cfr. con carácter general los estudios monográficos de A. Embid Irujo, Las Libertades en la Enseñanza, Tecnos, Madrid, 1983, y A. Fernández-Miranda Campoamor, De la Libertad de Enseñanza al Derecho a la Educación: derechos educativos en la Constitución Española, CEURA, Madrid, 1988.

${ }^{11}$ Sobre este particular, permítaseme la remisión a la concepción de derecho fundamental que se desprende de la obra colectiva Bastida/Villaverde/Requejo/Presno/Aláez/Fernández, Teoría General de los Derechos Fundamentales en la Constitución Española de 1978, Tecnos, Madrid, 2004.

12 B. Aláez Corral, El Derecho a la Educación del Menor como Marco Delimitador de los Criterios de Admisión a los Centros Escolares Sostenidos con Fondos Públicos, en Varios Autores, Escolarización del alumnado en el sistema educativo español: cuestiones jurídicas, Fundación Europea Sociedad y Educación, Madrid, pp. 92-95. En un sentido inverso, centrando el objeto del derecho del art. $27 \mathrm{CE}$ en la libertad de enseñanza, y viendo como resultado del mismo al derecho a la educación, véase con carácter general A. Fernández-Miranda Campoamor, De la Libertad de Enseñanza al Derecho a la Educación: derechos educativos en la Constitución Española, cit.

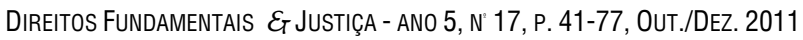


relación de instrumentalidad recíproca, en la que unas y otras son necesarias para su logro respectivo. La CE de 1978 garantiza, al igual que hace el art. 2 del Protocolo $n^{\circ} 1 \mathrm{CEDH}$, un derecho de prestación, no solo al mencionar el genérico derecho a la educación (27.1) y el "ideario constitucional" como su contenido pedagógico esencial (27.2), sino también al prever la intervención estatal en garantía del carácter obligatorio y gratuito de dicha educación democrática, por lo menos en sus niveles básicos (27.4), a través de una programación general de la enseñanza (27.5) y la inspección y homologación del sistema educativo (27.8). Dicho derecho prestacional a la educación no debe ser entendido en un sentido reduccionista como un poder del individuo para exigir una determinada prestación material, esto es, un determinado puesto escolar o concretos medios financieros para acceder al mismo, como las becas, lo que no garantiza directamente el texto constitucional sino en su caso la ley. Muy al contrario, este derecho de prestación lo es en un sentido amplio del término e implica un apoderamiento al individuo para exigir de los poderes públicos la organización de un sistema educativo que realice individualmente la recepción (en su caso gratuita) no sólo de una educación que transmita conocimientos de forma libre y plural, sino también que forme cívico-moralmente a la persona dentro de los valores democráticos del "ideario constitucional". La razón última de esta orientación finalista de la educación se halla en la instrumentalidad de la educación para la preservación y desarrollo del sistema constitucional democrático. Ciertamente, esta técnica protectora del derecho de prestación viene complementada con la técnica del derecho de libertad, que permite al individuo reclamar de los poderes públicos que se abstengan de interferir en la libertad de los particulares para, dentro de un sistema educativo jurídicamente reglado, ofrecer la prestación educativa mediante la libertad de enseñanza (art. 27.1) y la creación de centros docentes (art. 27.6), así como para elegir libremente a través de sus padres, la formación, filosófica y moral, que esté de acuerdo con sus convicciones (art. 27.3). Pero el hilo conductor del derecho del art. 27 es la educación, no la enseñanza ${ }^{13}$, pues sólo la educación, como resultado global de las instrumentales enseñanzas recibidas, puede y debe ser orientada a unas finalidades constitucional-democráticas,

\footnotetext{
${ }^{13}$ Cfr. STC 133/2010, de 2 de diciembre, FJ $7^{\circ}$. Sobre las diferencias entre ambas ya había reparado el voto particular del Magistrado Francisco Tomás y Valiente en la STC 5/1981, de 13 de febrero, y más recientemente en el ámbito del derecho comparado la Sentencia del Tribunal Constitucional Federal alemán sobre el crucifijo de 16 de mayo de 1995 (BVerfGE 93, 1). Mientras que la enseñanza es un proceso de transmisión de conocimientos y capacidades formativas al alumno, la educación es más bien un proceso de inculcación en éste de unas convicciones morales, filosóficas o religiosas, que en un Estado constitucional democrático como el nuestro sólo pueden consistir en la moral pública cívico-democrática que debe presidir la formación de las morales individuales paras la convivencia social. Es verdad que en la práctica es imposible distinguir entre una y otra por completo, pero no es menos cierto que en unas materias del currículo predomina más la función educativa -como es el caso de la Educación para la ciudadanía- mientras que en otras predomina más la enseñanza de conocimientos o capacidades -como las matemáticas, la física, la química, la lengua, etc...-
} 
sea cual sea el tipo de institución educativa -publica o privada- en la que se hayan recibido ${ }^{14}$.

De no optar por esta comprensión unitaria del derecho a la educación, se llegaría a la paradójica situación de contraponer diversas normas constitucionales que contendrían diversos derechos fundamentales necesitados de reconstrucción interpretativa ponderadora con la ayuda del principio de concordancia práctica ${ }^{15}$, principio que opera mucho más débilmente que la inicial construcción dogmática de unas y otras como facultades de un único derecho fundamental, lo que evita, en caso de contradicción irreconciliable de diversas conductas iusfundamentales, a tener que dar preferencia a unas facultades sobre otras (preferencia que no les ha dado el texto constitucional), mermando la eficacia obligatoria de la Constitución como norma suprema, así como del derecho a la educación del art. 27 en tanto que uno de sus contenidos.

\section{2.- ANTECEDENTES DEL IDEARIO EDUCATIVO CONSTITUCIONAL EN EL DERECHO INTERNACIONAL Y EN EL DERECHO EUROPEO COMPARADO}

El art. 27.2 CE dispone, como ya se ha dicho, que "la educación tendrá por objeto el pleno desarrollo de la personalidad humana en el respeto a los principios democráticos de convivencia y a los derechos y libertades fundamentales". En palabras del fallecido Magistrado del Tribunal Constitucional, Francisco Tomás y Valiente, establece su propio ideario educativo constitucional ${ }^{16}$, que se convierte en vinculante tanto para los poderes públicos como para los particulares involucrados en la satisfacción del derecho fundamental a la educación ${ }^{17}$. Al orientar la educación a la consecución de determinados fines, relacionados con la eficacia y garantía

\footnotetext{
${ }^{14}$ En este sentido, la STS de 11 de febrero de 2009 (Sala $3^{a}$ ), F.J. $6^{\circ}$ dice literalmente: "varias son las consecuencias que se derivan de una interpretación combinada de los dos anteriores preceptos constitucionales. La primera es que la actividad del Estado en materia de educación es obligada (representa el aspecto prestacional del derecho a la educación que resulta del precepto constitucional que se viene analizando). La segunda es que esa intervención tiene como fin no sólo (1) asegurar la transmisión del conocimiento del entramado institucional del Estado, sino también (2) ofrecer una instrucción o información sobre los valores necesarios para el buen funcionamiento del sistema democrático. Y la tercera es que ese cometido estatal, debido a la fuerte vinculación existente entre democracia y educación, está referido a toda clase de enseñanza: la pública y la privada."

${ }^{15}$ Una concordancia práctica que exige que, a la hora de resolver los problemas interpretativos, los bienes y derechos constitucionales se conciban de modo que cada uno de ellos pueda ser realizado, para lo cuál deben estar limitados recíprocamente de tal manera que ambos lleguen a alcanzar la óptima eficacia normativa posible; sobre la concordancia práctica como principio interpretativo constitucional, cfr. K. Hesse, Grundzüge des Verfassungsrechts der Bundesrepublik Deutschland (20ª edición), C.F. Müller, Heidelberg 1999, p. 28.

${ }^{16}$ Cfr. el Voto particular del Magistrado Francisco Tomás y Valiente en la STC 5/1981, de 13 de febrero.

${ }^{17}$ Cfr. G. Cámara Villar, "Sobre el Concepto y los Fines de la Educación en la Constitución Española", en Ministerio de Justicia (Edit.), X Jornadas de Estudios. Introducción a los Derechos Fundamentales, Vol. III, Dirección General del Servicio Jurídico del Estado, Madrid 1988, pp. 2185 ss.
} 
de los valores y principios democráticos y los derechos constitucionalmente garantizado, el texto constitucional está estableciendo una especie de ideario cívico-democrático que no solo es límite negativo sino que además de ve inspirar positivamente el proceso educativo en todos los centros de enseñanza, sea cual sea su titularidad ${ }^{18}$.

Semejantes previsiones finalistas relativas a la educación no son nuevas en el derecho internacional, pero tampoco son muy frecuentes en el derecho constitucional europeo comparado. A continuación se van a analizar los antecedentes del ideario educativo constitucional en los instrumentos internacionales de los que España es parte, así como sus manifestaciones en el derecho constitucional europeo comparado.

\section{a) Antecedentes en los Instrumentos Internacionales}

El derecho internacional de los derechos humanos -que conforme al art. 10.2 CE debe actuar como guía interpretativa de los derechos fundamentales reconocidos en el Título I CE, incluido el derecho a la educación- ya conocía a la entrada en vigor de la CE de 1978 la garantía del la subordinación del derecho a la educación a determinadas finalidades democráticas. Así, el art. 26.2 de la Declaración Universal de Derechos Humanos de 1948 (DUDH) es el primer instrumento internacional que dispone que la educación, a la que toda persona tiene derecho conforme al apartado 1 del citado art. 26, "tendrá por objeto el pleno desarrollo de la personalidad humana y el fortalecimiento del respeto a los derechos humanos y a las libertades fundamentales; favorecerá la comprensión, la tolerancia y la amistad entre todas las naciones y todos los grupos étnicos o religiosos, y promoverá el desarrollo de las actividades de las Naciones Unidas para el mantenimiento de la paz" (la cursiva es nuestra).

De forma casi idéntica, el art. 13. 2 del Pacto internacional de Derechos económicos, sociales y culturales de 1966 (PIDESC), también expresa el acuerdo de los Estados parte en que la educación se oriente finalísticamente "hacia el pleno desarrollo de la personalidad humana y del sentido de su dignidad", y favorezca "el respeto por los derechos humanos y las libertades fundamentales", así como en que la educación deba "capacitar a todas las personas para participar efectivamente en una sociedad libre, favorecer la comprensión, la tolerancia y la amistad entre todas las naciones y entre todos los grupos raciales, étnicos o religiosos, y promover las actividades de las Naciones Unidas en pro del mantenimiento de la paz " (la cursiva es nuestra). Concretando el sentido de este último precepto, el Comité de la ONU para el seguimiento del PIDESC considera en su comentario general sobre este art. 13 (E/C.12/1999/10) que los Estados Partes convienen que toda la enseñanza, ya sea pública o privada, escolar o extraescolar, debe orientarse hacia los propósitos y objetivos que se definen en el párrafo 1 del artículo 13. De todos esos objetivos de la educación, que son comunes al

\footnotetext{
${ }^{18}$ STC $5 / 1981$, de 13 de febrero, F.J. $7^{\circ}$
} 
párrafo 2 del artículo 26 DUDH y al párrafo 1 del artículo 13 PIDESC, el Comité considera que el fundamental es el que afirma que "la educación debe orientarse hacia el pleno desarrollo de la personalidad humana", que se repite también en nuestro art. 27.2 CE. Y también menciona el carácter evolutivo y dinámico de dichos abstractos objetivos educacionales, desarrollados en otros instrumentos internacionales como la Declaración Mundial sobre Educación para todos (Jomtien (Tailandia), 1990) (art. 1), la Convención de la ONU sobre los Derechos del Niño (párrafo 1 del artículo 29), la Declaración y Plan de Acción de Viena (parte I, párr. 33, y parte II, párr. 80), y el Plan de Acción para el Decenio de las Naciones Unidas sobre la educación en la esfera de los derechos humanos (párr. 2). Todos estos textos tienen grandes coincidencias con el párrafo 1 del artículo 13 PIDSEC, pero también incluyen elementos que no están contemplados expresamente en él, por ejemplo, referencias concretas a la igualdad entre los sexos y al respeto del medio ambiente, nuevos elementos que están implícitos y reflejan una interpretación contemporánea de aquél.

En este ámbito convencional universal, pero referido ya a los menores, colectivo humano que en principio es el destinatario esencial del derecho a la educación, el art. 29.1 de la Convención de la ONU sobre derechos del niño de 1989 (CDN) expresa el acuerdo de los Estados parte en que la educación tenga por objetivo: "a) desarrollar la personalidad, las aptitudes y la capacidad mental y física del niño hasta el máximo de sus posibilidades; b) inculcar al niño el respeto de los derechos humanos y las libertades fundamentales y de los principios consagrados en la Carta de las Naciones Unidas; c) inculcar al niño el respeto de sus padres, de su propia identidad cultural, de su idioma y sus valores, de los valores nacionales del país en que vive, del país de que sea originario y de las civilizaciones distintas de la suya; d) preparar al niño para asumir una vida responsable en una sociedad libre, con espíritu de comprensión, paz, tolerancia, igualdad de los sexos y amistad entre todos los pueblos, grupos étnicos, nacionales y religiosos y personas de origen indígena; e) Inculcar al niño el respeto del medio ambiente natural" (la cursiva es nuestra). Y el apartado $2^{\circ}$ del citado art. 29 CDN somete la libertad de los particulares y de las entidades para establecer y dirigir instituciones de enseñanza a la condición de que "respeten los principios enunciados en el párrafo 1 del presente artículo y de que la educación impartida en tales instituciones se ajuste a las normas mínimas que prescriba el Estado".

Como contraste, en el ámbito regional europeo tanto el art. 2 del Protocolo $\mathrm{n}^{\circ} 1 \mathrm{CEDH}$ como el art. 14 de la Carta Europea de Derechos Fundamentales (CEDF), guardan silencio en relación con los fines de la educación. Sin embargo, desde mediados de los setenta del siglo XX, el TEDH ha admitido que los Estados parte pueden establecer contenidos y objetivos educativos obligatorios de carácter moral, como la educación sexual, sin con ello conculcar el derecho de los padres a elegir la formación filosófica y moral que quieran para sus hijos, siempre que se consideren 
necesarios para satisfacer el derecho a la educación del niño, imprescindible para el libre desarrollo de su personalidad, y se impartan de manera objetiva, científica y pluralista ${ }^{19}$. Más en concreto, aunque sin valor jurídico directamente vinculante, el Comité de Ministros de los Estados miembros del Consejo de Europa aprobó el 16 de octubre de 2002 la Recomendación 12 (2002) relativa a la educación para la ciudadanía democrática, por la que recomendó a los Gobiernos de los Estados miembros, dentro del respeto de sus estructuras constitucionales, que, entre otros, hicieran de la educación para la ciudadanía democrática un objetivo prioritario de las políticas y reformas educativas; que fomentasen y apoyasen iniciativas que promuevan la educación para la ciudadanía democrática en los Estados miembros y entre ellos; y que en sus reformas educativas actuales o futuras tuviesen en cuenta los principios enunciados en el Anexo de la presente recomendación, entre los que se encuentran la inclusión con una metodología activa y participativa, asignada a disciplinas específicas o ámbitos de aprendizaje diversos o interdisciplinares, la educación cívica, política y relativa a los derechos humanos que enseñen a vivir juntos en una sociedad democrática, luchar contra el nacionalismo agresivo, el racismo y la intolerancia, y eliminar la violencia y las ideas y comportamientos extremistas.

\section{b) Manifestaciones en el Derecho Europeo Comparado}

Por lo que se refiere al derecho constitucional europeo comparado ${ }^{20}$, aunque existen antecedentes en el constitucionalismo de entreguerras de principios del siglo $X X^{21}$, tampoco son frecuentes en las Constituciones de los Estados europeos previsiones sobre los fines de la educación, aunque algunos textos constitucionales las hayan incorporado $y$, sobre todo, se admitan generalizadamente en el nivel legislativo y jurisprudencial infraconstitucional relativo a la satisfacción del derecho a la educación.

Entre los textos constitucionales que contienen dichas previsiones cabe destacar el art. 24.3 de la Const. de Bélgica, que dispone que "todos tienen derecho a la enseñanza en el respeto a las libertades y derechos fundamentales" (la cursiva es nuestra) ${ }^{22}$; el art. 73.2 de la Const. de Portugal

\footnotetext{
${ }^{19}$ Ya desde la STEDH de 7 de diciembre de 1976 (Caso Kjeldsen, Busk, Madsen y Pedersen contra Dinamarca), FFJJ 50-55.

${ }^{20}$ Aunque o es objeto de análisis aquí, también en el derecho constitucional de otros países, como los EEUU, aún sin una cobertura constitucional explícita a nivel federal -aunque sí parcialmente en las Constituciones de muchos Estados federados- se ha vinculado el deber constitucional de satisfacer el derecho a la educación con el logro de una finalidad social de eduar civico-democráticamente, que va más allá de los intereses particulares del educando o sus familias. Sobre ello cfr. K.A. Yuracko, Education Off the Grid: Constitutional Constrains on Homeschooling, California Law Review, Vol. 123 (2008), pp. 154-155.

${ }^{21} \mathrm{El}$ art. 148 de la Constitución alemana de Weimar de 1919 decía: "En todas las escuelas se procurará la formación moral, la educación cívica y el perfeccionamiento personal y profesional, todo ello conforme al espíritu del sentimiento alemán de humanidad y reconciliación entre los pueblos" (la cursiva es nuestra).

22 De conformidad con el cual, el Tribunal Constitucional belga (Staasthof) ha dispuesto en su Sentencia de 18 de febrero de 1998, que el deber de neutralidad que impone el art. 24.1 de
} 
conforme al cual: "el Estado promueve la democratización de la educación y de las demás condiciones para que la educación, realizada a través de la escuela y de otros medios formativos, contribuya a que la igualdad de oportunidades, la superación de las desigualdades económicas, sociales y culturales, el desarrollo de la personalidad y del espíritu de tolerancia, la comprensión mutua, y la solidaridad y la responsabilidad, para el progreso social y para la participación democrática en la vida colectiva" (la cursiva es nuestra); o el art. 16.2 Const. de Grecia, en virtud del cual "la instrucción constituye misión fundamental del Estado, y tendrá por objetivo la educación moral, cultural, profesional y física de los helenos, así como el desarrollo de su conciencia nacional y religiosa y su formación como ciudadanos libres y responsables" (la cursiva es nuestra). También, aunque más reducido en las finalidades educativas, cabe mencionar el art. 8 de la Carta del Medio Ambiente francesa, aprobada por la Ley constitucional $n^{\circ}$ 2005-205 del 1 de marzo de 2005 y parte integrante de la Const. Francesa según el Preámbulo de esta última, conforme al cual "la educación y la formación en el medio ambiente deben contribuir al ejercicio de los derechos y deberes definidos en la presente Carta" (la cursiva es nuestra). Pero, quizás, el texto constitucional más prolijo y a la vez literario en el establecimiento de fines educativos sea el art. 14.5a) de la Const. de Austria, en virtud del cual: "La democracia, la humanidad, la solidaridad, la paz y la justicia, así como la apertura y la tolerancia con las personas, son los valores fundamentales de la escuela, sobre los cuales ésta, con una garantía y desarrollo de la mejor calidad posible, asegura el nivel educativo más elevado posible a toda la población, con independencia de su origen, posición social y circunstancias económicas" (la cursiva es nuestra). Añade que "Mediante la colaboración solidaria de los alumnos, los padres y los docentes se ha de facilitar a la infancia y a la juventud el mejor desarrollo intelectual, espiritual y corporal posible, para que se conviertan en personas sanas, conscientes, felices, laboriosas, leales con sus deberes, de espíritu musical y creativo que, guiados por los valores sociales, religiosos y morales, sean capaces de asumir su responsabilidad para con ellos mismos, sus conciudadanos el medio ambiente y las generaciones futuras. Todo joven debe ser guiado, en función de su desarrollo y nivel educativo, a una decisión autónoma y socialmente responsable, debe estar abierto al pensamiento político, religioso e ideológico de los demás, y debe ser capacitado para participar en la vida cultural y económica de Austria, de Europa y del mundo, así como para cooperar en las misiones comunes de la humanidad con apego a la libertad y a la paz" (la cursiva es nuestra).

la Const. de Bélgica no priva al poder público del poder para -conforme al art.13.3 PIDSEC y al art. 29 CDN- establecer como orientaciones y fines mínimos del desarrollo educativo determinados valores, concepciones y actitudes, siempre que se trate de valores o concepciones que no se contrapongan a ninguno de los principios esenciales de una sociedad democrática.

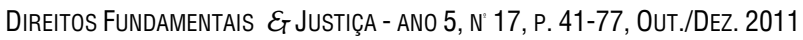


Con todo, la mayoría de los Estados Europeos están huérfanos de disposiciones constitucionales sobre los fines de la educación. No obstante, muchos han incorporado dichas orientaciones finalistas de la educación en disposiciones infraconstitucionales. Como ejemplo, baste mencionar el art. 12.2 de la Const. de Baden-Würtenberg, que dispone que "la juventud ha de ser educada en el respeto a Dios, en el espíritu cristiano del amor al prójimo, en la fraternidad de todos los hombres y en el amor a la paz, en el amor a pueblo y a la patria, en la responsabilidad moral y política en mérito profesional y social y en la convicción democrático-liberal".

El desarrollo en la legislación educativa de estos fines de la educación tanto en los Estados con disposiciones constitucionales al respecto, como en los huérfanos de éstas, se ha llevado a cabo básicamente conforme a tres modelos: de forma transversal, impregnando todas las materias de todos o varios de los niveles del currículo educativo obligatorio; a través de una asignatura específica de carácter genérico pero no específicamente cívico-política, como la asignatura de "Ética"; o finalmente, mediante una específica asignatura de educación cívico-democrática. Aunque en muchos de los Estados europeos se aprecian elementos de más de un modelo, dependiendo del nivel de enseñanza de que se trate, es posible simplificadoramente, observar la preponderante adscripción de unos y otros a cada uno de los tres modelos.

Al primer modelo corresponde, por ejemplo, Italia que ha introducido con la Ley $n^{\circ} 169$ de 30 de octubre de 2008 el proyecto experimental de enseñar con un horario propio y obligatorio pero como materia transversal, integrada en las áreas Historia-Geografía e Historia-Ciencias sociales, la materia "Cittadinanza e Costituzione", pero también Portugal, cuya Ley de bases del sistema educativo de 1986, desarrollada por Decretos-Legislativos de los años 2001 y 2004 en lo que se refiere al currículo de las enseñanzas de primaria y secundaria, ha optado por el carácter transversal a las diversas asignaturas de la Educación para la ciudadanía ${ }^{23}$.

Al segundo modelo pertenecen los Länder alemanes ${ }^{24}$. En ellos desde la década de 2000 y a pesar de contar con una fuerte tradición de enseñanza transversal de educación política en los diversos niveles del sistema educativo ${ }^{25}$, la asignatura de "Etica" es la utilizada mayoritariamente para desarrollar las finalidades constitucionales y legales de la educación ${ }^{26}$.

\footnotetext{
${ }^{23}$ Al respecto véase M.H. Salema, "Citizenship Education in Portugal", en The Making of Citizens in Europe, Bundeszentrale für politische Bildung, Bonn, 2008, pp. 110-111.

${ }^{24}$ Como pone de relieve el Informe de la Conferencia de Ministros de Educación alemana de 22 de febrero de 2008 sobre la situación en los distintos estados federados de la asignatura de "Ética". Véase dicho informe en: http://www.kmk.org/fileadmin/veroeffentlichungen_beschluesse/ 2008/2008_02_22-Situation-Ethikunterricht.pdf (visitado el 2 de marzo de 2011).

${ }^{25}$ Sobre esta enseñanza de la educación política en la escuela alemana véase, M. Elosegui Itxaso, La legislación vigente sobre la asignatura de educación política en las escuelas alemanas, Revista de Estudios Políticos, n 154,2011 , pp. 80 ss.

${ }^{26}$ Aunque no es ni ha sido la única asignatura en la que se han enseñado los contenidos de la
} 
Así, por ejemplo, el art. 12.6 de la Ley de educación del Land de Berlín, de 26 de enero de 2004, en desarrollo del art. 20.1 de la Constitución del Estado federado de Berlín, dispone la obligatoriedad de la asignatura "Ética" para todos los alumnos de las escuelas públicas durante la ESO, siendo el fin de esta asignatura preparar y capacitar a los alumnos con independencia de su origen cultural, étnico, religioso o ideológico, confrontarlos constructivamente con los problemas culturales y éticos fundamentales de la existencia individual y de la vida en sociedad, así como con las diferentes ofertas de valores y principios. A través de ella, los alumnos deberían alcanzar las bases de una vida consciente y responsable, así como adquirir las competencias sociales de la capacidad de juicio ético y del diálogo intercultural. Aunque la obligatoriedad de esta asignatura ha sido impugnada tanto ante la jurisdicción ordinaria como ante la jurisdicción constitucional alemana y europea, la impugnación ha sido infructuosa en todos los niveles, que han confirmado la constitucionalidad/convencionalidad de la obligatoriedad de esa materia con esos contenidos cívico-democráticos ${ }^{27}$.

Al tercer modelo pertenece, además de nuestra Ley Orgánica 2/2006 del Educación (LOE) que introduce la asignatura obligatoria "Educación para la ciudadanía" ${ }^{28}$, la legislación francesa ${ }^{29}$, cuyo art. L111-1 del Código de la Educación establece que "además de la transmisión de conocimientos, la Nación establece como primera misión de la escuela hacer partícipes a los alumnos de los valores de la República". Y el art. L121-1 del mismo Código dispone, entre otros muchos, como fines de todos los centros educativos los de contribuir a favorecer la mezcla y la igualdad entre hombres y mujeres, concurrir a una educación en la responsabilidad cívica y participar, con ello, en la prevención de la delincuencia, asegurar una formación en el conocimiento y el respeto de los derechos de la persona, y contribuir a la enseñanza de las diversas lenguas y culturas regionales, siendo el Anexo $\mathrm{V}$ de la parte reglamentaria del Código de la educación el que, de conformidad con los contenidos mínimos del currículo de la enseñanza obligatoria previstos en el art. L122-1-1 de dicho Código, establece los contenidos de la

educación para la ciudadanía; cfr. D. Lange, "Citizenship Education in Germany", en The Making of Citizens in Europe, cit., pp. 93-94. Además, el Informe de la Conferencia de Ministros de Educación alemana de 6 de marzo de 2009 sobre el refuerzo de la enseñanza de "Educación democrática" pone de relieve la necesidad de reforzar la enseñanza de la democracia desde un punto de vista transversal a todas las asignaturas. Véase el informe en: http://www.kmk.org/ fileadmin/veroeffentlichungen_beschluesse/2009/2009_03_06-Staerkung_Demokratieerziehung.pdf ${ }^{27}$ Véase, entre muchas, la BVerwG, de 17 de junio de 1998 - 6 C 11.97, relativa a la asignatura en Baden-Würtenberg, y el Auto del BVerfG, de 15 de marzo de 2007 - 1 BvR 2780/06 y la STEDH Appel-Irrgang y otros contra Alemania, de 2 de octubre de 2009, relativas a la asignatura en Berlín.

${ }^{28}$ Desarrollada por los Reales Decretos 1513/2006 de 7 de diciembre, por el que se regulan las enseñanzas mínimas de la Educación Primaria y 1631/2006 de 29 de diciembre, por el que se establecen las enseñanzas mínimas correspondientes a la Educación Secundaria Obligatoria.

${ }_{29}$ Sobre ello, cfr. E. Feron, "Citizenship education in France", en The Making of Citizens in Europe, cit., pp. 105-109.

DiREITOS FundAMENTAIS E E JUSTIÇA - ANO 5, N’ 17, P. 41-77, OUT./DEZ. 2011 
materia "Competencias sociales y cívicas", tanto en conocimientos como en capacidades y actitudes necesarios para vivir en sociedad y para prepararse para ser un ciudadano ${ }^{30}$.

De las disposiciones constitucionales y legislativas analizadas en el derecho europeo comparado, pero sobre todo de las normas internacionales y de su interpretación por los Comités de la ONU se desprenden, en mi opinión, cuatro ideas rectoras que pueden guiar la interpretación del art. 27.2 CE y de su eficacia normativa:

$1^{a}$ El Estado debe -no solo puede- organizar y programar la educación tanto pública como privada orientándola a la satisfacción de un ideario educativo democrático, sin que ello se pueda entender como una merma de la libertad de los padres para elegir la educación filosófica o moral que quieran para sus hijos, pues esta libertad está al servicio del derecho a la educación del menor.

$2^{\mathrm{a}}$ De ese ideario educativo forman parte como objetivos rectores de la satisfacción del derecho a la educación el pleno desarrollo de la personalidad y dignidad humana, el respeto a los derechos humanos y a las libertades fundamentales, la formación para la participación cívico-democrática y la tolerancia en pro de la paz.

$3^{a}$ Estos contenidos cívico-democráticos tienen un carácter dinámico, son ampliables en su formulación abstracta y pueden completarse con otros valores o principios que vayan surgiendo en función de la evolución social y de las particularidades históricas e identitarias de cada Estado, siempre que no choquen con el contenido matriz de ese ideario educativo democrático.

$4^{\mathrm{a}}$ Los medios para la realización de este objetivo quedan en manos del Estado, que puede para ello impregnar transversalmente con dicho ideario educativo democrático las diversas materias previstas en el currículo de las distintas etapas educativas o, por el contrario, puede complementaria o alternativamente introducir una nueva materia específica en el currículo cuyo objeto sea la enseñanza de ese ideario educativo democrático.

\section{3.- NORMATIVIDAD JURÍDICA DEL IDEARIO EDUCATIVO CONSTITUCIONAL}

Como se ha visto, la existencia de un ideario educativo constitucional no es algo desconocido ni por el derecho internacional de los derechos humanos, ni por las Constituciones/legislaciones de los Estados miembros de la Unión Europea. Sin duda que para determinar la concreta normatividad jurídica de este ideario educativo constitucional es preciso conocer cuáles

\footnotetext{
${ }^{30}$ En una línea semejante de combinar transversalidad curricular con una materia específica obligatoria en diversos niveles del sistema educativo está la Ley de educación griega 1566/85, Sobre ello, cfr. D. N. Chryssochoou, Making Citizenship Education Work: European and Greek perspectives, GreeSE Paper: Hellenic Observatory Papers on Greece and Southeast Europe, $\mathrm{N}^{\circ}$ 27, 2009, pp. 26-37. Y también adopta este modelo Eslovenia; cfr. M. Sardoĉ, "Citizenship Education in Slovenia", en The Making of Citizens in Europe, cit., pp. 120-123.
} 
son los concretos principios y valores que se establecen como objeto de este ideario y cual es su significado jurídico-constitucional. Antes, sin embargo, se debe analizar cuál es el contenido obligatorio y la función normativoconstitucional que posee dicho ideario, sobre todo a luz del art. 27.2 CE.

\section{a) Contenido Obligatorio y Función Normativa}

Partiendo de la premisa ya analizada, de que el art. 27 CE debe ser interpretado (al igual que sucede con el art. 1 del protocolo $\mathrm{N}^{\circ} 2 \mathrm{CEDH}$ ) como un único derecho complejo, del que forman parte diversos mandatos y libertades a desarrollar durante el proceso educativo para la satisfacción del derecho a la educación, y del carácter jurídicamente vinculante del art. 27.2 $\mathrm{CE}$, podemos decir que el contenido obligatorio del llamado ideario educativo constitucional del art. 27.2 CE consiste en un mandato a los poderes públicos y los particulares ordenándoles cuál debe ser el objetivo del derecho fundamental a la educación ${ }^{31}$ pública o privada, básica o superior, obligatoria o voluntaria. La obligatoriedad del ideario educativo constitucional abarca, pues, todas las facetas del sistema educativo programado por los poderes públicos para dar satisfacción al derecho a la educación (art. 27. $5 \mathrm{CE})^{32}$. Dado que pesa sobre ambos, poderes públicos y particulares, la estructura normativa en la que se despliega este mandato es dual, de regla y de principio $^{33}$, en consonancia con la diferente sujeción a la Constitución que, según reiterada jurisprudencia constitucional, poseen los ciudadanos particulares y los poderes públicos ${ }^{34}$ : respecto de los particulares opera como un una regla que fija el límite interno de las libertades educativas del art. 27 CE (libertad de enseñanza, de creación de centros, derecho a elegir la formación religiosa y moral, etc...). Como tal regla, implica el mandato definitivo de dejar fuera de la tutela constitucional aquellas conductas iusfundamentales que, encajando en abstracto en las libertades educativas mencionadas, se ven excluidas de ella en concreto por su desviación de las finalidades constitucionales a las que debe responder la educación.

\footnotetext{
31 Se utiliza aquí la clásica tripartición kelseniana del objeto de las normas jurídicas en mandatos permisos y prohibiciones; cfr. H. Kelsen, Reine Rechtslehre (2a edición), Scientia, Aalen 1960 , pp. 61 ss.

${ }^{32}$ Cabe preguntarse si vincularía incluso a la educación que tenga lugar fuera del sistema educativo reglado, como la que desarrollen las familias en sus casas o la que indirectamente se desprenda del ejercicio social colectivo de otras libertades como la de asociación, manifestación, expresión, etc... La reciente STC 133/2010, de 2 de diciembre, FJ 5ª), parece abonar esta idea, en la medida en que ha incluido dento de la libertad de enseñanza protegida por el art. 27.1 CE la que pueden desarrollar los padres sobre sus hijos en el ámbito doméstico familiar complementaria de la obligatoria reglada, y que por tanto estaría -según lo que aquí se sostiene- también sometida a la delimitación por el ideario educativo constitucional del art. 27.2 CE. En este mismo sentido ya, G. Cámara Villar, Sobre el Concepto y los Fines de la Educación en la Constitución Española, cit., pp. 2176-2177.

${ }^{33}$ Conforme a la distinción entre un tipo y otro de estructura de las normas de derechos fundamentales expuesta por R. Alexy, Theorie der Grundrechte (3 ${ }^{a}$ edición), Nomos, Baden-Baden, 1996, pp. 71 ss.

${ }^{34}$ Por todas, véase la STC $101 / 1983$, de 18 de noviembre, FJ $3^{\circ}$.
} 
Respecto de los poderes públicos opera como un principio que les ordena optimizar el logro de los fines a los que el art. 27.2 CE orienta la educación a través de sus competencias en materia educativa, tales como la organización y programación de la enseñanza, la satisfacción del derecho a la educación básica obligatoria y gratuita, la inspección y homologación del sistema educativo o las ayudas a los centros docentes privados. Como principio, aunque les obliga a adoptar las medidas necesarias en el marco de sus competencias para hacer efectiva la finalidad constitucional de la educación, deja en sus manos la decisión de política educativa acerca de qué medidas, cuándo y cómo es preciso adoptar.

A tenor de ese contenido obligatorio, ¿cuál es la función normativa del ideario educativo constitucional previsto en el art. 27.2 CE? Con carácter general se puede decir que la función del art. 27.2 CE es delimitar el objeto y el contenido del extenso y complejo derecho fundamental a la educación; excluyendo, de una parte, de la garantía de las libertades educativas aquellas conductas iusfundamentales menoscabadoras 0 impeditivas del logro de esa finalidad constitucional; y ordenando, de otra parte, a los poderes públicos ejercer sus poderes y diseñar sus políticas educativas de la forma que mejor satisfagan la educación en el ideario educativo constitucional. En otras palabras, se trata de un límite interno ${ }^{35}$ de las libertades y competencias educativas, que delimita el alcance de las primeras y orienta a las segundas. Así, por ejemplo, del mismo modo que no están protegidas por el art. 20.1.d) CE las informaciones inveraces (pues el precepto citado protege el derecho a comunicar "información veraz"), ni por el art. $21 \mathrm{CE}$ las reuniones y manifestaciones violentas o armadas (puesto que se requiere que sean pacíficas y sin armas), o que tampoco ampara el art. 22 CE las asociaciones secretas o paramilitares, el art. 27 CE tampoco protege las modalidades de educación o el ejercicio de la libertad de enseñanza que impliquen un menoscabo o un obstáculo para la formación del educando en el ideario educativo constitucional. Y ello, porque el art. 27.2 CE somete a la educación, que es el resultado global del ejercicio de los mandatos, permisos y prohibiciones educativas, contenidos en el art. $27 \mathrm{CE}$, a la finalidad obligatoria de orientarse al pleno desarrollo de la personalidad en el respeto a los derechos fundamentales y a los principios democráticos de convivencia. $\mathrm{Y}$, como se verá después, esta delimitación de las libertades educativas afecta no solo a los contenidos del currículo educativo, sino también a los métodos o procedimientos pedagógicos utilizados para educar ${ }^{36}$.

\footnotetext{
${ }^{35}$ Siguiendo la conceptualización sostenida por I. Villaverde Menéndez, Esbozo de una Teoría General de los Derechos Fundamentales, Revista Jurídica de Asturias, n²22, 1998, pp. 33 y ss. ${ }^{36}$ El ideario educativo democrático justifica hoy en día la consideración de la educación democrática como currículo oculto del sistema educativo, que defendió J. Dewey, Democracy and Education : an introduction to the philosophy of education, Macmillan, New York, 1916, para las escuelas públicas y que hoy vincularía constitucionalmente ex art. 27.2 CE a todos los centros educativos, públicos o privados.
} 
La clave de esta función delimitadora nos la da de forma expresa el art. 13.4 PIDESC, al disponer que "nada de lo dispuesto en este artículo se interpretará como una restricción de la libertad de los particulares y entidades para establecer y dirigir instituciones de enseñanza, a condición de que se respeten los principios enunciados en el párrafo 1 y de que la educación dada en esas instituciones se ajuste a las normas mínimas que prescriba el Estado." (la cursiva es nuestra). Ello pone de relieve que, en el caso concreto de la libertad de enseñanza, ésta tiene su límite en el respeto debido a los principios del párrafo 1 del art. 13, es decir, en el ideario educativo democrático que también recoge nuestro texto constitucional. $\mathrm{Y}$ este paradigma interpretativo sirve igualmente para fundamentar la delimitación del derecho de los padres a elegir la formación religiosa y moral que quieran para sus hijos previsto (art. 27.3 CE), entre otras formas eligiendo el centro que quieran para sus hijos. Como ha puesto de relieve el Comité de la ONU para el seguimiento del PIDSEC (E/C.12/1999/10), esta libertad de los padres y tutores legales de escoger para sus hijos o pupilos escuelas distintas de las públicas está condicionada, según el art. 13.4 PIDESC a que "satisfaga las normas mínimas que el Estado prescriba o apruebe" y a que respete "los objetivos educativos expuestos en el párrafo 1 del artículo 13 PIDESC". En esta misma línea, aunque la dicción literal del art. 27.2 CE refiera los objetivos a conseguir a la educación y no a la enseñanza, dado que la enseñanza es un instrumento para la satisfacción del derecho a la educación, la función normativa del ideario educativo de la constitución se despliega sobre todas las libertades educativas garantizadas por el art. $27 \mathrm{CE}$, se trate de libertades de enseñanza (art. 27.1 y $6 \mathrm{CE}$ ) o del derecho a elegir una educación religiosa o moral (art. 27.3 CE).

Por la misma razón, pero desde la perspectiva de los poderes públicos encargados de satisfacer el derecho a la educación, la función delimitadora de este ideario implica poner en manos de éstos la realización efectiva del mismo, aunque se deje a su libre decisión de política educativa la determinación del medio con el que conseguirlo. Es por ello que cabe tanto introducir específicas enseñanzas instrumentalmente dirigidas a lograr la función del ideario educativo constitucional, como han hecho los arts. 18 y 24 LOE, como mantener la transversalidad a todas las materias de la educación en y para el ideario educativo constitucional, como hacía la LOGSE, o combinarla con una materia de enseñanza específica ${ }^{37}$.

Esta función normativa del ideario educativo constitucional está íntimamente ligada a la necesidad de interiorización y preservación del

\footnotetext{
${ }^{37}$ Como pone de relieve A. Bolívar, La Educación para la Ciudadanía en el currículum de la LOE, Avances en Supervisión Educativa, $n^{\circ}$ 9, 2008, diversos estudios a nivel internacional constatan que, como también hemos vivido en España, si bien es una buena aspiración la transversalidad, conviene reforzarla con una materia o asignatura propia, como espacio de reflexión específica.
} 
sistema político democrático entre las generaciones futuras ${ }^{38}$, vital para la supervivencia del sistema jurídico democrático en sociedades altamente complejas $^{39}$. En el caso del art. 27.2 CE, se trata de contribuir preventivamente a construir el presupuesto de una democracia moderna ${ }^{40}$ : la existencia de ciudadanos libres e iguales con capacidad de participación en la formación de la voluntad colectiva ${ }^{41}$. Para ello la educación debe, desde los primeros momentos, contribuir al pleno desarrollo de la personalidad y dignidad del individuo, pero debe, al tiempo, prepararle para la vida en sociedad democrática, enseñándole el valor del respeto a los derechos fundamentales (propios y ajenos) y las reglas democráticas de convivencia establecidas por el texto constitucional. Es más, en una democracia no militante como la nuestra $^{42}$, la necesidad constitucional de preparar a los individuos desde la infancia a través del sistema educativo para el ejercicio de una ciudadanía democrática, es una premisa de la preservación y desarrollo del principio democrático mismo, que implica una toma de partido y cierta pérdida de neutralidad de la autoridad educativa del Estado.

La existencia de este ideario, como se ha visto con algunos ejemplos del derecho europeo comparado ${ }^{43}$, no quiebra la necesaria neutralidad estatal en materia educativa ${ }^{44}$, puesto que ésta se afirma con la finalidad de garantizar que el proceso educativo no constituya una vía para que el Estado menoscabe el pluralismo democrático garantizado constitucionalmente, no con la finalidad de que el Estado se abstenga de inculcar a los individuos a través del sistema educativo las premisas epistemológicas y axiológicas de

\footnotetext{
${ }^{38}$ Una funcionalización, que como pone de relieve M. Salguero, Socialización política y lealtad a la Constitución, Revista de Estudios Políticos, nº 97, 1997, pp. 320 ss., ya era habitual en los en la filosofía política desde Platón.

${ }^{39}$ La socialización que ha de promover la educación constituye un elemento esencial para el mantenimiento del sistema jurídico como subsistema de comunicación social, pues aporta a los individuos los códigos de comunicación válidos paran las distintas esferas comunicativas en las que pueden interactuar, entre ellas también la del sistema político y la del sistemá jurídico; sobre la educación como un elemento imprescindible para la socialización, cfr. N. Luhmann, Das Erziehungssystem der Gesellschaft, Suhrkamp, Frankfurt a.M., 2002, pp. 48 ss.

40 Sobre este valor de la educación para la democracia, cfr. H. Kelsen, Vom Wesen und Wert der Demokratie (reimpresión de la edición de 1929), Scientia, Aalen, 1994, p. 18.

${ }^{41}$ No se trata, pues, de que la función democrática del ideario sea formar a los educandos para que participen en una futura redefinición del modelo educativo existente (como sugiere L. Alvarez Alvarez, La Educación en el Estado Social y Democrático de Derecho. El Ideario Educativo en la Constitución Española, en Presno Linera/Sarlet (edits.), Los derechos sociales como instrumento de participación, Thomson Reuters/Aranzadi, Cizur Menor, 2010, pp. 222-223). Se trata más bien de que la educación en el modelo de democracia procedimental permita al educando cuestionar en el futuro entre muchos de los contenidos democrático-constitucionales también el modelo educativo constitucionalizado, aunque desde la perspectiva del mayor valor jurídico que éste tiene.

${ }^{42}$ Reiteradamente afirmado en la doctrina (I. de Otto y Pardo, Defensa de la Constitución y Partidos Políticos, CEPC, Madrid, 1985, pp 41 ss.) y por la jurisprudencia constitucional (por todas, STC 48/2003, de 12 de marzo, FF.JJ. $7^{\circ}-10^{\circ}$ ).

${ }_{3}$ Sentencia del Tribunal Constitucional belga de 18 de febrero de 1998.

${ }^{44}$ A. Embid Irujo, Las libertades en la enseñanza, Tecnos, Madrid, 1983, pp. 202-203.
} 
ese pluralismo democrático. De ahí que no sea extraño que la enseñanza obligatoria de ese ideario educativo democrático no se considere adoctrinamiento ${ }^{45}$, aunque lo sea de una doctrina lo suficientemente abierta y plural como para permitir el desarrollo de las doctrinas opuestas. Ello, si bien roza los contenidos normativos de la democracia militante, elude dicha calificación ${ }^{46}$ siempre que los principios democráticos de convivencia en los que se eduque al individuo sean los de una democracia procedimental que exponga el mayor valor conferido constitucionalmente a los valores democráticos y expresado en su rigidez procedimental, y al mismo tiempo admita su variabilidad y la persecución de cualesquiera fines y valores, incluidos los antiliberales o antidemocráticos ${ }^{47}$.

b) Caracterización de los Principios y Valores Constitucionales Objeto del Ideario Educativo Constitucional

La afirmación del ideario educativo constitucional en el art. 27.2 CE como mecanismo preventivo de autotutela del sistema constitucionaldemocrático implica el deber de orientar el proceso educativo a la formación del individuo en aquellos principios y valores que desempeñan un papel estructurador más importante dentro del sistema jurídico. Se trata de principios y valores relacionados con la concepción constitucional de Estado social y democrático de derecho, que tienen como sujeto central a la persona. En este sentido, el art. 27.2 CE menciona de forma expresa, como objetivos de la educación:

- el pleno desarrollo de la personalidad

- el respeto a los principios democráticos de convivencia

- el respeto a los derechos y libertades fundamentales

Estos tres contenidos del ideario, tomados aisladamente, reflejarían la tensión perenne entre los intereses del individuo y los de la sociedad. Sin embargo, la formulación utilizada por el art. 27.2 CE resuelve de forma elegante y salomónica esta tensión. Sólo se puede convivir bajo un sistema constitucional-democrático eficaz si los individuos son educados para desarrollar plenamente su personalidad, y ésta solo puede desarrollarse plenamente si se conocen los propios derechos y los derechos de los demás, se aprende a respetarlos y se interiorizan las reglas de convivencia propias de una sociedad democrática. El pleno desarrollo de la personalidad de los educandos está vinculado, pues, a la inculcación y disfrute de los derechos y libertades constitucionalmente reconocidos por un Estado

${ }^{45}$ Así, las Sentencias del Tribunal Supremo sobre la asignatura "Educación para la ciudadanía" de 11 de febrero de 2009 (sala $3^{a}$ ), FJ $6^{\circ}$.

${ }^{46}$ M. Salguero, Socialización Política y Lealtad a la Constitución, cit., p. 330.

${ }^{47}$ La educación debe permitir el desarrollo de la personalidad, pues, para el ejercicio de una ciudadanía activa, pero no para el ejercicio de una ciudadanía transformativa que aliente la desobediencia civil contra el sistema constitucional para promover una justicia social alternativa, como sin embargo, sugiere J.A. Banks, Diversity, Group Identity, and Citizenship Education in a Global Age, Educational Researcher, Vol. 37, No. 3, 2008, pp. 136-137. 
que quiera llamarse democrático. Es cierto que en el primer término de la frase aparece como objetivo de la educación el pleno desarrollo de la personalidad, y no el respeto a los principios democráticos de convivencia, pero aquél solo es posible en un Estado democrático en el que el individuo tiene reconocidos unos derechos fundamentales que le permiten disfrutar de su dignidad y desarrollar plenamente su personalidad ${ }^{48}$.

Ahora bien, en qué consistan estos valores y principios integrantes del ideario educativo constitucional es una cuestión clave para determinar su concreta eficacia normativa. No es posible hacer en estas páginas un análisis detallado de cada uno de los tres elementos que lo componen, que por sí mismo merecería un análisis monográfico extenso. Pero sí es posible indicar una premisa y tres elementos de dogmática constitucional que han de ser tenidos en cuenta a la hora de su reconstrucción interpretativa. La premisa es que se trata de contenidos de carácter autorreferente y positivizado, es decir, que remiten a los principios y valores constitucionalmente previstos; y los elementos de dogmática constitucional que los caracterizan son: su carácter abstracto, su carácter dinámico y la necesidad de completarlos con los principios y valores a los que los tratados internacionales orientan la educación.

Por lo que se refiere a la premisa: su naturaleza autorreferente $y$ positivizada, hay que decir que la mención en el art. 27.2 CE al pleno desarrollo de la personalidad, y al respeto a los principios democráticos de convivencia y de los derechos y libertades fundamentales, se refiere a valores y principios constitucionalizados, no a valores y principios metapositivos, ni tampoco a valores o principios desconocidos por el texto constitucional que deba definir y configurar autónomamente el legislador ordinario. Efectivamente, por obvio que resulte, hay que recordar que ya el art. 10.1 CE menciona el libre desarrollo de la personalidad, junto con la dignidad de la persona, como valor fundamentador del orden político y de la paz social; el art. 1 CE define nuestro Estado como un Estado social y democrático de derecho, cuyos valores superiores son la libertad, la justicia y el pluralismo político; y el Capítulo II del Título I CE, denominado "Derechos y libertades", recoge una serie de derechos fundamentales y libertades públicas, así como unos derechos y deberes de los ciudadanos (la cursiva esa nuestra). Así, pues, el libre desarrollo de la personalidad que hay que inculcar a los alumnos es el que está vinculado a la dignidad de la persona en el art. 10.1 CE en los términos en los que la ha concretado el Tribunal Constitucional ${ }^{49}$,

\footnotetext{
48 En un sentido parecido, llevando la cuestión al ámbito de la conciencia individual y a la necesaria complementariedad entre moral pública y moral privada, cfr. D. Llamazares Fernández, Educación para la Ciudadanía Democrática y Objeción de Conciencia (2a edición), Dyckinson, Madrid, 2010, pp. 80-83.

${ }^{49}$ Que no la considera un derecho fundamental autónomo sino un principio interpretativo de las relaciones sociales; cfr., entre varias, la STC 120/1990, de 27 de junio, FFJ $4^{\circ}$, sobre la huelga de hambre de los presos de la organización terrorista GRAPO.
} 
que se refleja y se hace posible a través del respeto al ejercicio de los concretos derechos fundamentales constitucionalmente garantizados. Igualmente, los principios democráticos de convivencia mencionados en el art. 27.2 CE se identifican con los principios de Estado social y democrático de derecho, Estado autonómico e integrado en la Unión Europea, conforme a lo dispuesto en los arts. 1, 2 y 93 CE, y tal y como han sido concretados en muchos otros preceptos constitucionales e interpretados por el Tribunal Constitucional $^{50}$. Ciertamente se puede formar a los educandos con un espíritu crítico en lo que se refiere a estas estructuras políticas, que pueden ser cambiadas incluso de forma completa -dado el carácter no militante de nuestra democracia-, pero siempre desde la premisa del conocimiento de su mayor valor constitucional, que procedimentalmente deben ser respetadas incluso por quienes pretendan cambiarlas. Por último, los derechos y libertades fundamentales cuyo respeto ha de ser inculcado a los educandos son los que conforme a nuestro texto constitucional merecen la consideración de tales, y no otros derechos subjetivos que, sin estar garantizados como derechos fundamentales por nuestro ordenamiento, pudieran ser considerados por los educadores merecedores de atención. Además, la inculcación de su respeto está íntimamente vinculada a su formación en el libre desarrollo de su personalidad, pues, en la medida en que la dignidad de la persona y el libre desarrollo de su personalidad no son en nuestro sistema constitucional un derecho fundamental autónomo sino el reflejo de los concretos derechos fundamentales garantizados, solo se puede desarrollar la person valores $y$ alidad en términos constitucionalmente correctos si se aprende a ejercer los derechos fundamentales propios y a respetar el ejercicio de los derechos fundamentales de los demás.

En lo que respecta a las características dogmático-constitucionales de estos elementos del ideario educativo constitucional, hay que señalar, en primer lugar, que se trata de valores y principios abstractos ${ }^{51}$, mucho más que otras las disposiciones constitucionales, pues se corresponden con los denominados principios estructurales y valores fundamentales del ordenamiento, así como con los derechos y libertades fundamentales. Para reducir esta abstracción no cabe acudir a la precomprensión política o moral que cada intérprete tenga de lo que sean libre desarrollo de la personalidad, democracia o tal o cual derecho fundamental. Es preciso servirse de, un lado,

50 La jurisprudencia constitucional que reconoce los mencionados principios como los fundamentales es para cada uno de ellos muy abundante; baste citar ahora como ejemplificativas del contenido constitucional de los principios estructuradores de nuestro sistema constitucional de convivencia la STC 81/1982, de 21 de diciembre (Estado social y democrático de derecho); la STC 76/1994, de 14 de marzo (monarquía parlamentaria); la STC 48/2003, de 12 de marzo (democracia no militante); la DTC 1/2004, de 13 de diciembre (integración en la Unión Europea); la STC 103/2008, de 11 de septiembre (democracia constitucional); y la STC 31/2010, de 28 de junio (Estado autonómico).

51 Cfr. G. Cámara Villar, Sobre el Concepto y Fines de la Educación en la Constitución Española, cit., p. 2169. 
del propio texto constitucional, que sistemáticamente los desarrolla en disposiciones orgánico-procedimentales (sobre las Cortes, las elecciones, el procedimiento legislativo, el gobierno, el poder judicial, el Tribunal Constitucional, etc...) o en disposiciones dogmático-axiológicas (la concreta regulación de cada derecho fundamental recogido en el Título I). Pero también es preciso acudir a los intérpretes constitucionales previstos por la Constitución, de entre los cuales, el supremo en materia de garantías constitucionales es el Tribunal Constitucional (arts. 123, 161 y $163 \mathrm{CE}$ ), y el que posee una mayor capacidad de concreción es el legislador orgánico u ordinario, que es llamado expresamente por el texto constitucional (arts. 53.1 y $81 \mathrm{CE}$ ) a desarrollar (concretar) el sentido de las disposiciones sobre derechos fundamentales y, con ello, del libre desarrollo de la personalidad, así como de la mayoría de los aspectos inconcretos de nuestro sistema democrático de convivencia.

El segundo elemento, ligado a dicha abstracción y al carácter necesariamente abierto de toda constitución democrática, es que se trata de valores cuyo concreto contenido normativo es dinámico y evoluciona con la sociedad, siendo, como se ha dicho, el legislador quien en primer término concrete esta dinámica evolutiva, y el Tribunal Constitucional el llamado en segundo término a concretar los límites de evolución de ese contenido normativo de los principios y valores del ideario educativo constitucional ${ }^{52}$. De ahí, que los principios y valores del ideario educativo constitucional se definan y redefinan en el tiempo con la ayuda del supremo interprete constitucional y su jurisprudencia sobre el concepto de derecho fundamental, la titularidad de los derechos fundamentales, el concepto constitucional de igualdad o de familia, el derecho a la vida, la libertad religiosa, la naturaleza jurídico-constitucional de la dignidad de la persona y el libre desarrollo de su personalidad, el alcance del principio democrático, la titularidad y ejercicio de los derechos de participación política, etc...., vinculante para todos en los términos previstos en el art. 164 CE, art. 1 LOTC y art. 5.1 LOPJ. Por tanto, las cuestiones moralmente polémicas, a las que se refieren las SSTS de 11 de febrero de 2009 (Sala $3^{\mathrm{a}}$ ), FJ 4º , sobre la asignatura "Educación para la ciudadanía", como excluidas de los contenidos valorativos a los que se puede lícitamente referir el currículo de citada asignatura, no pueden serlo, lógicamente, las cuestiones controvertidas respecto de las cuales el Tribunal

\footnotetext{
${ }^{52}$ No se pretende caer en el activismo judicial que se deriva de la declaración del Presidente de la Corte Suprema de los EEUU en 1907, Charles Hughes, de que "la Constitución es lo que los jueces dicen que es", puesto que parto de que el texto constitucional posee un significado normativo autónomo y propio deducible del conjunto de sus prescripciones interpretadas de forma concordante conforme a la dogmática adecuada a cada texto constitucional ( $F$. Bastida Freijedo, La interpretación de los derechos fundamentales, en Bastida/Villaverde/Requejo/ Presno/Aláez/Fernández (edits.), Teoría general de los derechos fundamentales en la Constitución española de 1978, cit, p...), pero sí que son los tribunales, y en especial el Tribunal Constitucional, los llamados a deducir ese significado normativo autónomo implícito en los abstractos enunciados constitucionales.
} 
Constitucional ha concretado su contenido mínimo constitucionalmente declarado, puesto que ello sería tanto como negar carácter vinculante a las normas constitucionales deliberadamente abstractas y abiertas y sobre todo a las funciones de supremo intérprete constitucional que el Título XIX CE confiere al Tribunal Constitucional.

El tercer y último elemento, se refiere a que se trata de valores $y$ principios que no se agotan en su comprensión constitucional interna, sino que -dada la eficacia interpretativa de los tratados internacionales sobre derechos humanos que impone el art. 10.2 CE- se hayan internacionalizados y vinculados a los valores y principios relacionados con éstos que recogen el art. $26 \mathrm{DUDH}$, el art. 13.2 PIDSEC y el art. $29 \mathrm{CDN}^{53}$ como fines de la educación, entre los que han de incluirse: la participación efectiva en una sociedad libre, la comprensión, la tolerancia y la amistad entre todas las naciones y entre todos los grupos raciales, étnicos o religiosos, la promoción de las actividades de las Naciones Unidas en pro del mantenimiento de la paz, el respeto de sus padres, de su propia identidad cultural, de su idioma y sus valores, de los valores nacionales del país en que vive, del país de que sea originario y de las civilizaciones distintas de la suya; la responsabilidad, la igualdad de los sexos y por último el respeto del medio ambiente natural ${ }^{54}$.

\section{c) Concreción Legislativa en España}

El legislador democrático español ha adoptado básicamente dos posturas en estos más de treinta años de democracia en relación con la adaptación del sistema educativo al cumplimiento del ideario educativo constitucional: la transversalidad de los principios y valores que debían impregnar todas las materias del currículo ninguna de las cuales se orientaba materialmente a su inculcación ${ }^{55}$; y la combinación de la transversalidad de dichos principios y

${ }^{53}$ Cfr. G. Cámara Villar, Sobre el Concepto y Fines de la Educación en la Constitución Española, cit. pp. 2182-2183.

${ }^{54}$ El texto de la Constitución no es, pues, la única fuente de la que extraer estos valores y principios de ideario, como sostiene B. Vila Ramos, La formación del ciudadano: un camino hacia la democracia participativa, Comunicación y Hombre. Revista Interdisciplinar de Comunicación y Humanidades, $n^{\circ} 4,2008$, pp. 12-13, achacándole extralimitación a los Reales Decretos sobre el currículo de la educación primaria y la secundaria obligatoria por incluir valores como tolerancia, solidaridad paz, respeto, etc...

${ }^{55}$ El art. 2 de la Ley Orgánica 8/1985, de 3 de julio (LODE), dispone que "La actividad educativa, orientada por los principios y declaraciones de la Constitución, tendrá, en los centros docentes a que se refiere la presente Ley, los siguientes fines:

a) El pleno desarrollo de la personalidad del alumno.

b) La formación en el respeto de los derechos y libertades fundamentales, de la igualdad entre hombres y mujeres y en el ejercicio de la tolerancia y de la libertad dentro de los principios democráticos de convivencia.

c) La adquisición de hábitos intelectuales y técnicas de trabajo, así como de conocimientos científicos, técnicos, humanísticos, históricos y estéticos.

d) La capacitación para el ejercicio de actividades profesionales.

e) La formación en el respeto de la pluralidad lingüística y cultural de España.

f) La preparación para participar activamente en la vida social y cultural.

g) La formación para la paz, la cooperación y la solidaridad entre los pueblos y para la 
valores en las materias del currículo (prevista en la LODE desde 1985) ${ }^{56}$ con la introducción de una materia específica dedicada a la inculcación de los contenidos del ideario en las etapas de Educación primaria y de Educación secundaria, así como la expresa mención de esos contenidos en la materia Filosofía ya existente en la etapa del Bachillerato (previsto todo ello por la LOE desde 2006) $)^{57}$.

Los fines de la educación previstos en la LODE, como concreción de la opción por la transversalidad del ideario educativo constitucional, nunca fueron cuestionados en sede judicial o doctrinal. Sin embargo, la expresa previsión de una materia específica del currículo ha sido objeto de cuestionamiento doctrinal, y sobre todo de recursos judiciales, que han obtenido una primera respuesta casi definitiva con las ya mencionadas Sentencias del Tribunal Supremo de 11 de febrero de 2009 (Sala 3 ${ }^{a}$ ), afirmativas de la constitucionalidad de la asignatura "Educación para la ciudadanía", aunque está pendiente un recurso de amparo ante el Tribunal Constitucional y se augura también -en caso de que éste sea igualmente

prevención de conflictos y para la resolución pacífica de los mismos y no violencia en todos los ámbitos de la vida personal, familiar y social".

${ }^{56} \mathrm{El}$ art. 2.1 LOE, reitera los valores y principios que como fines genéricos, deben guiar transversalmente al sistema educativo:

a) El pleno desarrollo de la personalidad y de las capacidades de los alumnos.

b) La educación en el respeto de los derechos y libertades fundamentales, en la igualdad de derechos y oportunidades entre hombres y mujeres y en la igualdad de trato y no discriminación de las personas con discapacidad.

c) La educación en el ejercicio de la tolerancia y de la libertad dentro de los principios democráticos de convivencia, así como en la prevención de conflictos y la resolución pacífica de los mismos.

d) La educación en la responsabilidad individual y en el mérito y esfuerzo personal.

e) La formación para la paz, el respeto a los derechos humanos, la vida en común, la cohesión social, la cooperación y solidaridad entre los pueblos así como la adquisición de valores que propicien el respeto hacia los seres vivos y el medio ambiente, en particular al valor de los espacios forestales y el desarrollo sostenible.

f) El desarrollo de la capacidad de los alumnos para regular su propio aprendizaje, confiar en sus aptitudes y conocimientos, así como para desarrollar la creatividad, la iniciativa personal y el espíritu emprendedor.

g) La formación en el respeto y reconocimiento de la pluralidad lingüística y cultural de España y de la interculturalidad como un elemento enriquecedor de la sociedad.

h) La adquisición de hábitos intelectuales y técnicas de trabajo, de conocimientos científicos, técnicos, humanísticos, históricos y artísticos, así como el desarrollo de hábitos saludables, el ejercicio físico y el deporte.

i) La capacitación para el ejercicio de actividades profesionales.

j) La capacitación para la comunicación en la lengua oficial y cooficial, si la hubiere, y en una o más lenguas extranjeras.

k) La preparación para el ejercicio de la ciudadanía y para la participación activa en la vida económica, social y cultural, con actitud crítica y responsable y con capacidad de adaptación a las situaciones cambiantes de la sociedad del conocimiento.

${ }^{57}$ El art. 18.3 LOE (respecto del tercer ciclo de la educación primaria) y el art. 24.3 LOE (respecto de uno de los tres cursos de la educación secundaria) prevén que los alumnos cursen la materia específica "Educación para la ciudadanía y los derechos humanos". Y el art. 34.6 LOE prevé que en los dos cursos de bachillerato se curse la asignatura "Filosofía y ciudadanía". 
infructuoso- un recurso ante el TEDH. Si dejamos a un lado la concreta opción por la transversalidad o especificidad curricular de la transmisión del ideario educativo constitucional, cuestión que, como se ha dicho, entra dentro de la decisión política del legislador, lo cierto es que cabe aventurar una respuesta de las instancias jurisdiccionales constitucional y europea similar a la del Tribunal Supremo, es decir, que ni el texto de la LOE ni los Anexos de los Reales Decretos 1513/2006, de 7 de diciembre, y 1631/2006, de 29 de diciembre, por los que se establecen los contenidos mínimos de las enseñanzas del currículo de Educación primaria y de Educación secundaria, ni tampoco los homónimos Decretos de las CCAA conculcan las libertades educativas del art. $27 \mathrm{CE}$, ni por una delimitación excesiva o inadecuada de la libertad de los padres para elegir la formación religiosa y moral que esté de acuerdo con sus convicciones, ni por un adoctrinamiento moral de los poderes públicos de los menores que implique desviarse del ideario educativo constitucional y, por tanto, del mandato del art. 27.2 CE.

Nada en la concreción legislativa del ideario educativo constitucional se aparta de su caracterización constituciona ${ }^{58}$. La asignatura "Educación para la ciudadanía" pretende integrar en el sistema educativo la educación en las reglas básicas de convivencia democrática y el respeto a los derechos fundamentales, como única forma de conseguir el libre desarrollo de la personalidad que la Constitución promueve. Por ello, conocer y respetar la Constitución y las leyes no discriminando, ni injuriando, ni siendo intolerantes con lo diferente, no es una opción moral más por la que puedan optar los padres en el proceso educativo, sino que es la moral pública que se deriva del pluralismo constitucional y que el propio texto constitucional obliga a inculcar a los educandos, siendo una asignatura específica en la que esto se ponga en práctica un medio idóneo para ello. Ello, sin perjuicio, de que algunos textos escolares o algunas prácticas docentes puedan puntualmente, al impartir la citada asignatura, apartarse de esta caracterización del ideario educativo constitucional ${ }^{59}$, pero no más de lo que se apartan de la objetividad y el rigor científico o del pluralismo algunos textos respecto de cuestiones de materias históricas o filosóficas, sin que hasta la fecha se haya cuestionado la obligatoriedad de estas últimas materias del currículo . Para realizar un juicio crítico de los textos o de las prácticas docentes en esta asignatura es preciso tener en cuenta la caracterización normativa antes realizada del ideario educativo constitucional. Cuando no se tiene en cuenta y se intentan reconstruir sus abstractos contenidos a partir de la

\footnotetext{
${ }^{58}$ Sobre ello, cfr. B. Aláez Corral, Ideario educativo constitucional y respeto a las convicciones morales de los padres. A propósito de las Sentencias del Tribunal Supremo sobre "Educación para la ciudadanía", El Cronista del Estado Social y Democrático de Derecho, nº 5, 2009, pp. 32-33, y B. Aláez Corral, "Caso Folgero y respeto a las convicciones morales de los padres en materia educativa", Revista Aranzadi del Tribunal Constitucional, $n^{\circ} 3,2008$, pp. 27-29.

${ }_{59}$ Cuyo control competería a los órganos administrativos y a la jurisdicción contenciosoadministrativa ordinaria, tal y como han declarado las citadas SSTS de 11 de febrero de 2009 (Sala $3^{\mathrm{a}}$ ), FJ $15^{\circ}$.
}

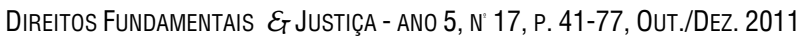


precomprensión política (liberal, marxista, católica, atea, etc...) de cada uno es cuando el acuerdo sobre un mínimo común ético que pretende expresar el art. 27.2 CE deviene inoperante. Y es también cuando resulta imposible el acuerdo respecto del desarrollo por parte de las distintas opciones políticas de ese mínimo común ético debido a que existe una fuerte resistencia por parte de diversos sectores de la sociedad a aceptar que los principios que deben regir la conducta individual en una sociedad democrática, y en los que hay que educar a nuestros menores, son en primer término los derivados de la moral pública cívica establecida por la Constitución y sus intérpretes, y solo después -o en un segundo plano procedimental- los de la concreta moral individual que cada uno pueda tener ${ }^{60}$.

Por tanto, no se trata de inculcar a los alumnos un juicio moral sobre el aborto, el género, la homofobia, la inmigración, los estereotipos o los prejuicios sociales, sino el deber jurídico de conocimiento y respeto de la moral pública cívico-democrática sobre estas cuestiones ${ }^{61}$, que delimita la extensión admisible de las convicciones morales y religiosas de los centros educativos, de los padres y de los mismos educandos, y que afirma, por ejemplo, la necesidad de conciliar la protección de la vida del nasciturus con la despenalización parcial del aborto, la necesidad de combatir la discriminación de género, la necesidad de respeto y tolerancia para con las diversas orientaciones sexuales, la garantía constitucional de derechos civiles, sociales y políticos para los inmigrantes, o la protección constitucional de una diversidad de modelos de familia ${ }^{62}$. La resistencia a aceptar que las personas deben ser educadas por mandato constitucional en ese respeto a ese marco democrático por encima de la concreta moral individual o familiar que sus padres les quieran inculcar es lo que lleva a ciertos sectores sociales a cuestionar las formas beligerantes y explícitas de introducción de ese ideario educativo constitucional, como la asignatura "Educación para la ciudadanía". Aunque el carácter abierto de nuestra democracia permita la ulterior discrepancia ideológica o moral respecto de dichos contenidos, constitucionalmente no es lícita la sustracción de los educandos a su conocimiento y, sobre todo, a su inculcación en la práctica educativa, dado que los mismos forman parte del ideario educativo constitucional tal y como lo han concretado los intérpretes constitucionales.

\footnotetext{
${ }^{60}$ En lugar de conciliarlas para que la moral pública permita el adecuado desarrollo de las conciencias privadas con la máxima libertad posible, como sugiere, D. Llamazares Fernández, Educación para la Ciudadanía Democrática y Objeción de Conciencia, cit., pp. 110-113.

${ }^{61}$ A la que ya había hecho referencia el propio Tribunal Supremo en su STS de 14 de abril, de 1998 (Sala 3a), FJ $4^{\circ}$.

${ }^{62}$ Cfr., entre otras, la STC 53/1985, de 11 de abril, STC 212/1996, de 19 de diciembre, y STC 1116/1999, de 17 de junio (protección de la vida del nasciturus como un bien y no como un sujeto de derechos); la STC 59/2008, de 14 de mayo (perspectiva de género); la STC 222/1992, del 11 de diciembre (diversidad de modelos de familia); la STC 154/2002, de 18 de julio (autonomía del menor); o la STC 236/2007, de 7 de noviembre (derechos fundamentales de los inmigrantes).
} 
4.- ALGUNOS EJEMPLOS DE DELIMITACIÓN DE LAS LIBERTADES EDUCATIVAS A LA LUZ DEL IDEARIO EDUCATIVO CONSTITUCIONAL

A continuación, se verán algunos ejemplos de cómo funciona el ideario educativo constitucional en la delimitación de las libertades educativas. Aunque estas libertades son numerosas y abarcan conductas que van desde la libertad pedagógica en la enseñanza, hasta la libertad de creación de centros docentes, pasando por la libertad de cátedra o el derecho de los padres a escoger la formación religiosa y moral para sus hijos que esté de acuerdo con sus convicciones, nos vamos a centrar en los aspectos pedagógicos de libertad de enseñanza de los centros docentes y en el derecho de los padres a escoger la formación religiosa y moral para sus hijos que esté de acuerdo con sus convicciones, oponiéndose para ello a ciertas formas o contenidos educativos. En uno y otro caso, como se verá seguidamente, el ideario educativo constitucional permite excluir ciertas conductas del ámbito de garantía iusfundamental de estas libertades que se ven, de este modo, delimitadas.

a) Delimitación de la Libertad de Enseñanza de los Centros Escolares Privados: posible inconstitucionalidad de la enseñanza diferenciada

La libertad de enseñanza garantiza, entre otras conductas, la libertad para crear centros docentes y para enseñar en ellos con el fin de satisfacer el derecho a la educación, incluso disfrutando de un ideario propio, de modo que exprese en el ámbito educativo el pluralismo ideológico existente en la sociedad. Un ámbito en el que se está expresando de forma singular en los últimos tiempos es el de la introducción de técnicas pedagógicas como la educación diferenciada con el fin de combatir los desiguales resultados instructivos de niños y niñas en ciertas materias del currículo ${ }^{63}$.

La respuesta a la pregunta que surge inmediatamente de si esta opción pedagógico-educativa de la educación segregada por sexos está amparada por el art. $27 \mathrm{CE}$ viene en buena medida determinada por su compatibilidad con el ideario educativo constitucional. No existe jurisprudencia constitucional ni europea al respecto. Desde un punto de vista meramente estadístico, es minoritaria en Europa la opción por la educación diferenciada, aunque sí está extendida en algunas materias como educación sexual, educación para la salud ${ }^{64}$, siendo el Reino Unido el Estado europeo en el que es más habitual. Con todo, la prueba de fuego a la que se debe someter jurídicoconstitucionalmente esta opción pedagógica no es la de si obtiene mejores o peores resultados desde el punto de vista del rendimiento instructivo de los

\footnotetext{
${ }^{63}$ Un análisis de su compatibilidad con el texto constitucional se puede ver en B. Aláez Corral, El ideario educativo constitucional como fundamento de la exclusión de la educación diferenciada por razón de sexo de la financiación pública, Revista Española de Derecho Constitucional, N 86,2009 , pp. 31 ss.

${ }^{64}$ Cfr. EURYDICE, Gender Differences in Educational Outcome. Study on Measures Taken and the Current Situation in Europe, Education, Audiovisual and Culture Executive Agency/European Commision, Brussels, 2010, p. 85-88.
} 
alumnos, sino la de si el resultado educativo de dichos alumnos se mantiene dentro de las finalidades que marca el ideario educativo de la Constitución ${ }^{65}$. Debe recordarse que, conforme a la caracterización anterior del derecho a la educación, los contenidos finalistas obligatorios del art. 27.2 CE se conciben como ideario constitucional de la "educación" a la que sirven instrumentalmente las diversas "enseñanzas" impartidas. El marco constitucional no solo condiciona la admisibilidad de ciertas técnicas pedagógicas a que los alumnos de uno y otro sexo alcancen el objetivo de recibir una instrucción completa, formativa y equivalente, esto es una enseñanza de calidad, sino también a que mediante dicha instrucción de calidad se logre inculcar a los educandos unas convicciones filosóficas y morales presentes en el ideario constitucional, esto es, a que el proceso educativo contribuya a educar cívico-democráticamente a los alumnos. Por tanto, las medidas que podrían tener un resultado beneficioso respecto de la enseñanza podrían, sin embargo, ser perjudiciales respecto de la educación cívico-democrática que es, en último extremo, sobre la que pivota todo el sistema del art. $27 \mathrm{CE}$. Téngase en cuenta en este sentido, además, que nuestro Tribunal Constitucional no tiene una opinión muy favorable hacia que las diferencias biológicas de sexo puedan ser por sí mismas el criterio justificativo de una diferencia de trato, y sin embargo sí las acepta cuando se trata de diferencias de género favorables a la mujer ${ }^{66}$, a cuya superación no parece contribuir precisamente, por lo menos en el aspecto cívico-educativo, la educación diferenciada.

Con lo anterior, se rinde tributo, además, al hecho de que el auténtico sujeto central del derecho a la educación y, por tanto, el beneficiario directo en unos casos -derecho de prestación- y reflejo en otros -libertad de enseñanza, libertad de elección de centro o libertad de elección de la formación religiosa y moral acorde con sus convicciones- es el alumno ${ }^{67}$, que ejerce dichos derechos por sí mismo cuando tiene la capacidad de

${ }^{65}$ Cfr. la STC 5/1981, de 13 de febrero, F.J. $8^{\circ}$ y la STC 77/1985, de 27 de junio, F.J. $10^{\circ}$. No parecen entender que deba someterse a esa delimitación algunos de sus defensores, como M. Calvo Charro, Apoyo de la jurisprudencia española a la educación diferenciada como una opción legítima dentro de la libertad de elección de centro docente de los padres, La Ley, $\mathrm{N}^{\circ} 6711,2007$, pp. 4 ss., con base en una jurisprudencia contencioso-administrativa de Tribunales Superiores de Justicia (STSJ de La Rioja de 25 noviembre de 2002 y STSJ de Castilla-La Mancha de 10 de noviembre de 2004), que se está viendo modificada paulatinamente por la última jurisprudencia del Tribunal Supremo (STS de 26 de junio de 2006 Sala $3^{\text {a }}$-, FJ $8^{\circ}$ y STS de 16 de abril de 2008 -Sala 3.a-, FJ 9), que niega al establecimiento de una metodología de educación diferenciada el carácter de contenido ni esencial ni adicional del derecho fundamental a la libertad de enseñanza (en su faceta de dirección del centro docente privado) con amparo precisamente en el desarrollo que del mismo habían hecho la LODE y la LOCE en relación con los conciertos escolares.

${ }^{66}$ Cfr. STC 198/1996, de 4 de diciembre, FJ 4, respecto de las diferencias biológicas de sexo, y la ya múltiples veces citada STC 59/2008, de 10 de mayo, FFJJ $7^{\circ}-9^{\circ}$, respecto de combatir mediante la diferenciación penal la desigualdad de género.

${ }^{67}$ Sobre ello, véase R. Sánchez Ferriz, El artículo 27.2 de la Constitución Española. Contenido y fines de la educación, Revista General del Derecho, № 609, 1995, pp. 6495 ss. 
obrar iusfundamental necesaria -mayor edad o madurez suficiente, según determine la legislación vigente-, o a través de su representante legal cuando carece de ella ${ }^{68}$. Sólo orientando el contenido normativo del derecho a la educación a la formación en el ideario democrático de la Constitución es posible proteger adecuadamente los intereses de quien es menor de edad y garantizar con ello, su progresivo ejercicio por sí mismo de sus derechos fundamentales y, con ello, al libre desarrollo de su personalidad ${ }^{69}$.

Desde una perspectiva más concreta, nuestra legislación educativa vigente -arts. 2.a) y b) LODE y 2.a) y b) LOE- incluye entre los fines últimos a los que debe servir la educación la transmisión del valor de la igualdad entre hombres y mujeres y la prohibición de discriminación por razón de sexo, concretando así los contenidos de ese ideario educativo constitucional en lo que se refiere a la educación en el respeto a los derechos fundamentales y los principios democráticos de convivencia. Dichos preceptos dan, además, cumplimiento en el ámbito educativo al mandato del art. 9.2 CE, de remover los obstáculos que impiden que la libertad y la igualdad de los individuos y de los grupos en que se integra sea real y efectiva, y convierten aquel valor y aquella prohibición de discriminación del art. 14 CE en parte del límite constitucional al ejercicio de las distintas facultades iusfundamentales que forman el contenido subjetivo del derecho a la educación.

No se trata, pues, de que el modelo pedagógico de la educación diferenciada se oponga a la prohibición de discriminación por razón de sexo del art. $14 \mathrm{CE}^{70}$, sino de que la pedagogía de la educación diferenciada, basada en una organización (general o parcial) de la enseñanza a partir de la segregación de los alumnos con base en las diferencias psicobiológicas derivadas de su sexo, pone en peligro la garantía del derecho a la educación conforme al ideario educativo constitucional, y muy particularmente se aleja disfuncionalmente del objetivo de una formación actual en el respeto de los derechos y libertades fundamentales, la igualdad entre hombres y mujeres y el ejercicio de la tolerancia y la libertad dentro de los principios democráticos de convivencia. Ni el art. 26 DUDH, ni el art. 13 PIDSEC, ni el art. 2.a) de la Convención de la UNESCO de 1960 aportan claridad al respecto ${ }^{71}$, puesto que este último precepto no impone la licitud de semejante tipo de educación sino que únicamente la permite mediante una excepción a la regla general

\footnotetext{
${ }^{68}$ B. Aláez Corral, Minoría de Edad y Derechos Fundamentales, cit., pp. 198-208.

69 B. Aláez Corral, Minoría de Edad y Derechos Fundamentales, cit., p. 114

70 Conforme al art. 2.a) Convención de la UNESCO de 1960 relativa a la lucha contra las discriminaciones en la esfera de la enseñanza, no puede considerarse discriminación por razón de sexo el que los establecimientos o centros educativos reserven la admisión a alumnos sólo del sexo masculino o sólo del sexo femenino siempre que los diversos centros ofrezcan facilidades equivalentes a todos para el acceso a la enseñanza, con personal docente de igual cualificación, en locales y con equipamientos de igual calidad y de modo que tanto los de un sexo como los de otros puedan seguir los mismos o equivalentes programas de estudio.

${ }^{71}$ Cfr. STS de 26 de junio de 2006 (Sala $3^{\mathrm{a}}$ ), FJ $8^{\circ}$.
} 
del art. 1.1.c), aplicable en el caso de que el Estado admita una separación con aquellas garantías, lo que devuelve al ámbito del Derecho interno de cada Estado, en este caso a la CE de 1978 y las leyes orgánicas que lo desarrollen, la determinación de si semejante tipo de educación diferenciada por razón de sexo es o no constitucionalmente lícita ${ }^{72}$. Más bien al contrario, el art. 10.c) de la citada Convención de la UNESCO parece abonar la idea de la mayor idoneidad de la coeducación -y la correlativa menor idoneidad de la educación diferenciada- para satisfacer este aspecto concreto del ideario educativo constitucional relacionado con la lucha contra la discriminación de género, al ordenar expresamente a los Estados "la eliminación de todo concepto estereotipado de los papeles masculino y femenino en todos los niveles y en todas las formas de enseñanza, mediante el estímulo de la educación mixta y de otros tipos de educación que contribuyan a lograr este objetivo y, en particular, mediante la modificación de los libros y programas escolares y la adaptación de los métodos de enseñanza". Aunque el precepto no excluye otros tipos de educación distintos de la mixta, sí parece que no los equipara y que da cierta preferencia al estímulo de la coeducación -expresamente mencionada- sobre otros tipos de educación como la diferenciada.

Lo anterior, sin conducir a la inconstitucionalidad per se de los modelos pedagógicos de la educación diferenciada, sí los deja cuando menos fuera del contenido esencial del derecho a la educación, o si se prefiere de las libertades de enseñanza y de creación de centros docentes. Debe ser el Parlamento, en tanto expresión de la soberanía de las generaciones vivas, quien determine, en desarrollo de los arts. 9.2 y $27 \mathrm{CE}$, cuáles son los conceptos estereotipados de los papeles masculino y femenino que han de ser desterrados de la sociedad y cuáles las medidas razonablemente adecuadas para educar conforme a una igualdad real y efectiva de hombres y mujeres. Tarea suya es también explorar si las hay y cuáles pueden ser las vías neutrales a través de las cuales cabe equiparar a niños y niñas en el acceso a un proceso educativo que les produzca el mismo rendimiento en términos de calidad de la enseñanza y de la educación en valores democráticos, pudiendo prohibir, si lo estima pertinente, la educación diferenciada. En este sentido, aunque en nuestro país no hay un pronunciamiento legal expreso al respecto de la conformidad 0 disconformidad de la educación diferenciada con el ideario educativo constitucional, el legislador (arts. 2.b LODE y 2.b LOE) ha trazado ya algunas pautas definitorias que, al incluir la formación en el respeto de la

${ }^{72}$ B. Alaez Corral, El Ideario Educativo Constitucional como Fundamento de la Exclusión de la Educación Diferenciada por Razón de Sexo de la Financiación Pública, cit., pp 44-46. A favor de la considerar las mencionadas normas internacionales el aval de la licitud de la educación diferenciada, sin embargo, J.L. Martínez López-Muñiz, Siete Tesis sobre la Legalidad de la Educación Escolar Especializada por Razón de Sexo, 2007: http://www.diferenciada.org/ section.php?id=26\&id_element=172 (visitado el 02-05-2011). 
igualdad entre hombres y mujeres entre los fines de la educación, colocan a la educación diferenciada por razón de sexo bajo la sospecha de ser disfuncional para lograr una educación dentro del ideario constitucional. Esto se ve reforzado por la previsión legal de exclusión de la discriminación por razón de sexo en la admisión de los alumnos en los centros sostenidos con fondos públicos (art. 84 LOE), su sometimiento al principio de no discriminación (art. 121.2 LOE) y por el mandato de preferencia de la coeducación respecto de los conciertos educativos (DA $\left.20^{\mathrm{a}} \mathrm{LOE}\right)^{73}$.

b) La Delimitación del Derecho de los Padres a escoger formación Religiosa y Moral: no ampara la objeción parental a la enseñanza reglada o a asignaturas cívico-democráticas

Un segundo ámbito de libertades educativas en las que el ideario educativo constitucional juega un papel delimitador es el del derecho de los padres a escoger la formación religiosa y moral para sus hijos que esté de acuerdo con sus convicciones, que podría llevar a éstos a objetar bien la inserción de sus hijos en todo el sistema de enseñanzas regladas por el Estado pretendiendo educarlos en el ámbito doméstico-familiar (homeschooling), bien a algunas materias o asignaturas que consideran adoctrinamiento estatal contrario a sus convicciones religiosas o morales (como las asignaturas de Educación sexual o más recientemente en España, la asignatura de Educación para la ciudadanía democrática y los derechos humanos). La expresión objetar se utiliza aquí en un sentido genérico de la palabra y en ningún caso como sinónimo de un derecho fundamental a la objeción de conciencia educativa, ni autónomo ni genéricamente derivado del art. $16.1 \mathrm{CE}^{74}$.

Como ya se ha dicho, de la jurisprudencia constitucional se desprende que la presencia del ideario educativo constitucional en el art.- 27.2 CE implica que el derecho a la educación, y por tanto también la facultad de los padres de elegir la formación religiosa y moral para sus hijos que esté de acuerdo con sus convicciones (art. 27.3 CE), no es neutral desde un punto de vista moral y debe orientarse -positivamente- a la impregnación del educando de ciertos valores que constituyen una moral cívico-democrática ${ }^{75}$, deshaciendo cualquier equívoco respecto a la posible neutralidad axiológica del Estado en la tarea educativa del Estado ${ }^{76}$. Muy recientemente, nuestro

\footnotetext{
${ }^{73}$ Cfr. STS de 16 de abril de 2008 (Sala $3^{a}$ ), FJ $9^{\circ}$.

${ }^{74}$ Expresamente negado por las SSTS de 11 de febrero de 2009 (Sala $3^{\mathrm{a}}$ ) sobre Educación para la ciudadanía, e implícitamente por reiterada jurisprudencia constitucional (STC 160/1987, de 27 de octubre, FJ $3^{\circ}$ y muchas otras posteriores). Sobre ello cfr. B. Aláez Corral, Caso Folgero y Respeto a las Convicciones Morales de los Padres en Materia Educativa, cit. pp. 22-25. y Llamazares/Tejón/Celador, Educación e Ideología, Dykinson, Madrid, 2010, pp. 158-162, aunque desde una comprensión diferente de la objeción de conciencia.

${ }_{70}^{75}$ Cfr. STC 5/1981, de 13 de febrero, FJ $7^{\circ}$.

${ }^{76}$ En este mismo sentido ya en los noventa la STS de 14 de abril de 1998, F.J. $4^{\circ}$ (Sala de lo Contencioso-Administrativo), decía: ".....es observable en el precepto que tanto los sujetos como el objeto de la educación están perfectamente sistematizados en los apartados 1 y 2 y que de este sistema no puede excluirse el hecho de que a la finalidad de la educación se le asigna por
} 
Tribunal Constitucional ${ }^{77}$ ha afirmado de forma contundente que ni la libertad de enseñanza ni el derecho de los padres a que los hijos reciban una formación religiosa y moral que esté de acuerdo con sus propias convicciones amparan -ni siquiera prima facie- la facultad de elegir para sus hijos una educación ajena al sistema de escolarización reglada obligatoria, facultad que por otra parte ni siquiera está reconocida con rango legal en nuestro vigente sistema educativo a tenor de los dispuesto tanto en el art 9 de la derogada Ley Orgánica 10/2002, de 23 de diciembre de calidad de la educación (LOCE) como en el art. 4.2 de la vigente LOE, que afirman la obligatoriedad de la escolarización reglada y convierten el homeschooling en una conducta ilegal ${ }^{78}$.

Lo anterior se inserta en la línea de jurisprudencia del TEDH que admite que los Estados parte establezcan contenidos y objetivos educativos obligatorios de carácter moral, como la asignatura Educación sexual, sin con ello conculcar el derecho de los padres a elegir la formación filosófica y moral que quieran para sus hijos, garantizado por el art. 2 del Protocolo $\mathrm{n}^{\circ} 1 \mathrm{CEDH}$, siempre que se consideren necesarios para satisfacer el derecho a la educación del niño, imprescindible para el libre desarrollo de su personalidad, y se impartan de manera objetiva, científica y pluralista $^{79}$. Y más allá, afirma, correlativamente, las condiciones o requisitos para que las convicciones filosóficas y religiosas de los padres sean respetadas por el Estado, entre las que están que la mismas sean merecedoras de respeto en una sociedad democrática, no sean incompatibles con la dignidad de la persona, y, sobre todo, que están subordinadas funcionalmente a la satisfacción del derecho a la educación del menor ${ }^{80}$. Y la satisfacción de este derecho puede llevar al Estado a establecer la obligatoriedad de la

el texto constitucional un contenido que bien merece la calificación de moral, entendida esta noción en un sentido cívico y aconfesional: pleno desarrollo de la personalidad humana en el respeto a los principios democráticos de convivencia y a los derechos y libertades fundamentales. Este ámbito subjetivo y teleológico de la educación, fijado en los apartados 1 y 2 , es el que delimita el sistema unitario y obligatorio que a todos alcanza. Más allá, el apartado 3 , se mueve ya en el terreno de la relevancia de las libres convicciones de cada cual, siendo el mensaje constitucional que de él se deriva el del respeto a la libertad de los ciudadanos para que puedan elegir para sus hijos una formación religiosa y moral de acuerdo con aquéllas, entendido esto como un plus, que atiende a quienes tienen creencias religiosas o valoraciones morales específicas, que siendo compatibles con los objetivos descritos en el apartado 2 como obligatorios para toda educación, sin embargo no están comprendidos necesariamente en los mismos...".

${ }^{77}$ STC 133/2010, de 2 de diciembre, FJ $5^{\circ}$. Esta sentencia resuelve negativamente, de forma semejante a como se ha hecho en otros países europeos (Auto del BVerfG alemán de 29 de abril de 2003 y Auto del BVerG alemán de 30 de mayo de 2006), y muy de forma muy distinta a la permisividad de la sociedades paralelas que sentó la Corter Suprema de los EEUU en el caso Wisconsin v. Yoder (406 US 205) de 1972, la cuestión de si el art. 27.3 CE garantiza una facultad parental para el homeschooling y la objeción al sistema de escolarización obligatoria reglado, que había dejado sin resolver ya en los años noventa la STC 260/1994, de 3 de octubre. ${ }^{78} \mathrm{Cfr}$. STC $133 / 2010$, de 2 de diciembre, FJ $4^{\circ} \mathrm{b}$ ).

${ }^{79}$ STEDH de 7 de diciembre de 1976 (Caso Kjeldsen, Busk, Madsen y Pedersen v. Denmark), FFJJ 50-55.

${ }^{80}$ STEDH de 25 de febrero de 1982 (Caso Campbell and Cosans v. United Kingdom), FJ 36 . 
escolarización reglada ${ }^{81}$ y la obligatoriedad de una asignatura en la que se enseñen valores comunes cívico-democráticos, como la Ética ${ }^{82}$, parangonables a los del ideario educativo constitucional que en España refleja la asignatura "Educación para la ciudadanía". La educación en el libre desarrollo de la personalidad, el respeto a los principios y valores democráticos, así como en el respeto a los derechos fundamentales, constituye, sin duda alguna, un valor mínimo a observar en la convivencia social democrática y un medio necesario para la realización de la dignidad de la persona, pues hace que a los alumnos se les inculque el respeto a su propia dignidad y a la de los demás, por lo que no se sale fuera del las exigencias del TEDH subordinar las facultades de los padres para elegir o exigir respeto a sus convicciones filosóficas o religiosas en la educación de sus hijos a su correlación con este ideario educativo constitucional ${ }^{83}$, que requiere socialización para que la educación democrática pueda tener lugar. ${ }^{84}$

Un segundo elemento a tener en cuenta en la delimitación por el ideario educativo constitucional de las facultades parentales de elección de la formación religiosa y moral para sus hijos que estén de acuerdo con sus convicciones, es que, de conformidad con la concepción unitaria del derecho a la educación del art. $27 \mathrm{CE}$ (igualmente sostenida por el TEDH respecto del art. 2 del Protocolo $\mathrm{n}^{\circ} 1 \mathrm{CEDH}$ ) y con el art. 3.1 en relación con el art. 29 CDN, dicho derecho parental no se puede entender reconocido en beneficio propio de los padres, sino en beneficio de la satisfacción del derecho a la educación de los hijos, una educación que ha de tener lugar dentro del pluralismo democrático. Los padres ejercerían, por así decirlo, una facultad en beneficio y por representación del hijo mientras éste carezca de madurez como para autodeterminar su ideología y su conciencia por sí mismo ${ }^{85}$.

\footnotetext{
${ }^{81}$ Cfr. primero la Comisión en la SCEDH de 6 de marzo de 1984, (Caso Family H. v. United Kingdom) y la SCEDH de 9 de julio de 1992 (Caso Leuffen v. Germany); y después el Tribunal en la STEDH de 25 de mayo de 2000 (Caso Jiménez Merino v. Spain), FJ 10, y STEDH de 11 de septiembre de 2006 (Caso Konrad and Others v. Germany), FJ $1^{\circ}$.

${ }^{82}$ Cfr. STEDH de 6 de octubre de 2009 (Caso Appel-Irgang and Others v. Germany).

${ }^{83}$ Con las propias palabras de la STC 133/2010, de 2 de diciembre, FJ 70: "La educación a la que todos tienen derecho y cuya garantía corresponde a los poderes públicos como tarea propia no se contrae, por tanto, a un proceso de mera transmisión de conocimientos [cfr. art. $2.1 \mathrm{~h}$ ) LOE], sino que aspira a posibilitar el libre desarrollo de la personalidad y de las capacidades de los alumnos [cfr. art. 2.1 a) LOE] y comprende la formación de ciudadanos responsables llamados a participar en los procesos que se desarrollan en el marco de una sociedad plural [cfr. art. $2.1 \mathrm{~d}$ ) y k) LOE] en condiciones de igualdad y tolerancia, y con pleno respeto a los derechos y libertades fundamentales del resto de sus miembros [cfr. art. 2.1 b), c) LOE].....Este objetivo, complejo y plural, es el que, conforme al art. $27.2 \mathrm{CE}$, ha de perseguir el legislador y el resto de los poderes públicos a la hora de configurar el sistema de enseñanza dirigido a garantizar el derecho de todos a la educación, y el mandato de su consecución es el principio constitucional al que sirve la imposición normativa del deber de escolarización en el marco de la enseñanza básica obligatoria (arts. 9.2 LOCE y 4.2 LOE)"

${ }^{84}$ STC 133/2010, de 2 de diciembre, FJ $8^{\circ}$ b) y STEDH de 11 de septiembre de 2006 (Caso Konrad and Others v. Germany) FJ $1^{\circ}$.

${ }^{85}$ En este sentido, B. Aláez Corral, Minoria de Edad y Derechos Fundamentales, cit., pp.
} 
Por ello, dogmas filosóficos o religiosos que pretendan superponerse a los valores comunes cívico-democráticos, expresión de la moral pública recogida en el art. 27.2 CE como ideario educativo constitucional, que no solo no se oponen al derecho a la educación del educando menor, sino que contribuyen a que la misma sirva para el libre desarrollo de su personalidad dentro de ese pluralismo democrático, no pueden entenderse amparados por el derecho a elegir del art. 27.3 CE. Igualmente, por la misma razón, la sustracción del educando menor de edad a la socialización e integración necesarias para el aprendizaje de los principios y valores necesarios para su convivencia democrática respetando los derechos de los demás y desarrollando libremente su personalidad, sea no escolarizándole, sea objetando en su nombre a la asignatura Educación para la ciudadanía, implican una lesión de su derecho a la educación (art. 27.1 CE) y no está amparada por el derecho de los padres a elegir la formación religiosa y moral del art. 27.3 $\mathrm{CE}^{86}$.

Ahora bien, para que todo lo anterior sea así, se requiere que tanto el sistema educativo reglado como las materias o asignaturas obligatorias se mantengan inspiradas positivamente por el mandato constitucional de transmitir un sistema de valores cívico-democrático que contribuya al libre desarrollo de la personalidad del educando y a su formación como un miembro activo de la sociedad democrática, y no se conviertan en un mecanismo de adoctrinamiento en una moral o religión particular de un individuo o un grupo ${ }^{87}$, pues esto último sí que conculcaría la facultad de los padres para que se respeten sus convicciones morales o religiosas, imprescindible para que la correcta transmisión pluralista de aquél sistema de valores democrático sirva al desarrollo de la personalidad del niño. ¿Dónde termina, pues, el constitucional adoctrinamiento en la moral pública del ideario educativo constitucional y dónde comienza el adoctrinamiento moral o religioso del Estado que es inconstitucional? Los casos Folgerø o Zengin de reciente resolución por el TEDH no resultan trasladables para la solución de esta cuestión en el ordenamiento constitucional español, porque los Estados de Noruega y Turquía respectivamente se adentran en el terreno de los valores religiosos que, al encontrarse al margen del sistema de valores constitucional-democráticos, no operan convencionalmente -ni tampoco constitucionalmente en España- como un adecuado criterio de delimitación de la facultad de los padres para que se respeten sus convicciones morales y/o religiosas, de ahí que el TEDH afirmara como necesaria la previsión de un mecanismo con las adecuadas garantías que permita a los padres evitar el adoctrinamiento religioso-moral de sus hijos por esta vía ${ }^{88}$.

\footnotetext{
${ }^{86} \mathrm{Cfr}$. expresamente respecto del homeschooling la STC 133/2010, de 2 de diciembre, FJ $7^{\circ} \mathrm{c}$ ).

${ }^{87}$ Como sucede, por ejemplo, con la obligatoriedad de una asignatura de religión confesional: STEDH 14 de febrero de 2006 (Caso Folgero and Others v. Norway).

${ }_{88}$ B. Aláez Corral, Caso Folgero y Respeto a las Convicciones Morales de los Padres en Materia Educativa, cit. pp. 27-29.
} 
Pero cuando la materia educativa no tiene naturaleza religiosa y es aparentemente neutra desde el punto de vista valorativo -como la asignatura de educación sexual-, o cuando la materia, aún teniendo naturaleza valorativa, lo que persigue transmitir al alumno es el ideario educativo constitucional -como en el caso de la Educación para la Ciudadanía-, así como cuando de lo que se trata es de objetar al conjunto del sistema educativo reglado por el Estado para educar en casa, sí que cabe extraer de la jurisprudencia europea algunos criterios con los que realizar esta valoración. De un lado, el TEDH, a fin de evitar que el Estado caiga en el adoctrinamiento contrario a las convicciones de los padres, exige desde la Sentencia del Caso Kjeldsen v. Denmark ${ }^{89}$ que la cientificidad y pluralismo sean los criterios rectores de la impartición de la materia, y que en aquellos aspectos de la asignatura que inevitablemente reflejen cuestiones de carácter moral, los mismos tengan carácter general y se circunscriban a la persecución del interés público en una sociedad democrática, requisitos todos ellos que reunía la asignatura sobre educación sexual del caso y que no parece que no pueda reunir la asignatura "Educación para la ciudadanía", toda vez que la educación cívico democrática, en tanto que prevista en el ideario educativo constitucional, es un interés general de la sociedad democrática española ${ }^{90}$. Y de otro lado, el TEDH también ha afirmado que los Estados pueden establecer la obligatoriedad de la escolarización reglada con base entre otras razones en el objetivo de la integración y la socialización del educando menor, y que esa obligación no supone una limitación desproporcionada del derecho de los padres a elegir la formación religiosa y moral para sus hijos que este de acuerdo con sus convicciones ${ }^{91}$.

\section{REFERENCIAS}

ALEXY, Robert. Theorie der Grundrechte. 3a ed. Baden-Baden: Nomos, 1996.

ALVAREZ, L. Alvarez. La Educación en el Estado Social y Democrático de Derecho. El Ideario Educativo en la Constitución Española. In: LINERA, Miguel Angel Presno; SARLET, Ingo W. (Eds.). Los Derechos Sociales como Instrumento de Participación. Thomson Reuters/Aranzadi, Cizur Menor, 2010.

\footnotetext{
${ }^{89}$ STEDH de 7 de diciembre de 1976, FFJJ 50-55.

${ }^{90}$ Cfr. la STS de 11 de febrero de 2009 (Sala $3^{a}$ ) FFJJ $12^{\circ}-14^{\circ}$. Además, la STC 5/1981, de 13 de febrero $\mathrm{FJ} 8^{\circ}$, ya había dicho explícitamente respecto del derecho a establecer un ideario en un centro escolar privado, derecho emparentado aunque no idéntico con el derecho de los padres a escoger formación religiosa y moral para sus hijos de acuerdo son sus convicciones, que éste pude moverse "dentro del marco de los principios constitucionales, del respeto a los derechos fundamentales, del servicio a la verdad, a las exigencias de la ciencia y a las restantes finalidades necesarias de la educación mencionadas, entre otros lugares, en el art. 27.2 de la Constitución y en el art. 13.1 del Pacto Internacional sobre Derechos Económicos, Sociales y Culturales ...”.

91 Cfr. SCEDH de 6 de marzo de 1984, (Caso Family H. v. United Kingdom); SCEDH de 9 de julio de 1992 (Caso Leuffen v. Germany); STEDH de 25 de mayo de 2000 (Caso Jiménez Merino v. Spain), FJ 10; y STEDH de 11 de septiembre de 2006 (Caso Konrad and Others v. Germany), FJ $1^{\circ}$.
} 
BANKS, James A. Diversity, Group Identity, and Citizenship Education in a Global Age. Educational Researcher, Vol. 37, No. 3, 2008.

BOLÍVAR, A. La Educación para la Ciudadanía en el Currículum de la LOE. Avances en Supervisión Educativa, n 9, 2008.

CAMPOAMOR, A. Fernández-Miranda. De la Libertad de Enseñanza al Derecho a la Educación: derechos educativos en la Constitución Española. Madri: CEURA, 1988.

CHRYSSOCHOOU, D. N. Making Citizenship Education Work: European and Greek perspectives, GreeSE Paper: Hellenic Observatory Papers on Greece and Southeast Europe, № 27, 2009.

CORRAL, B. Aláez. Caso Folgero y Respeto a las Convicciones Morales de los Padres en Materia Educative. Revista Aranzadi del Tribunal Constitucional. n 3, 2008.

El Derecho a la Educación del Menor como Marco Delimitador de los Criterios de Admisión a los Centros Escolares sostenidos con fondos públicos. In: VILLAR, Mercedes de Esteban (Coord.). Escolarización del Alumnado en el Sistema Educativo Español: cuestiones jurídicas. Madri: Fundación Europea Sociedad y Educación, 2006.

El Ideario Educativo Constitucional como Fundamento de la Exclusión de la Educación Diferenciada por Razón de Sexo de la Financiación Pública. Revista Española de Derecho Constitucional. N 86, 2009.

Ideario Educativo Constitucional y Respeto a las Convicciones Morales de los Padres. A Propósito de las Sentencias del Tribunal Supremo sobre "Educación para la Ciudadanía". El Cronista del Estado Social y Democrático de Derecho, $\mathrm{n}^{\circ} 5$, 2009.

Minoría de Edad y Derechos Fundamentals. Madri: Tecnos, 2003.

DEWEY, J. Democracy and Education: an introduction to the philosophy of education. New York: Macmillan, 1916.

EURYDICE. Gender Differences in Educational Outcome. Study on Measures Taken and the Current Situation in Europe. Bruxelas: Education, Audiovisual and Culture Executive Agency/European Commision, 2010.

FERNANDÉZ, D. Llamazares. Educación para la Ciudadanía Democrática y Objeción de Conciencia. $2^{\mathrm{a}}$ ed. Madri: Dyckinson, 2010.

FERON, E. Citizenship education in France. In: The Making of Citizens in Europe. Bonn: Bundeszentrale für politische Bildung, 2008.

FERRIZ, R. Sánchez. El Artículo 27.2 de la Constitución Española. Contenido y fines de la educación. Revista General del Derecho. № 609, 1995.

FREIJEDO, F. Bastida. La Interpretación de los Derechos Fundamentals. In: LINERA, Miguel Angel Presno et al. Teoría General de los Derechos Fundamentales en la Constitución Española de 1978. Madri: Tecnos, 2004.

GUTMANN, A. Democratic Education. New Jersey: Princeton University Press, 1999. HESSE, Konrad. Grundzüge des Verfassungsrechts der Bundesrepublik Deutschland. $20^{\mathrm{a}}$ ed. Heidelberg: C.F. Müller, 1999.

IRUJO, A. Embid. Las Libertades en la Enseñanza. Madri: Tecnos, 1983.

ITXASO, M. Elosegui. La Legislación vigente sobre la Asignatura de Educación Política en las Escuelas Alemanas. Revista de Estudios Políticos. n 154, 2011. 
KELSEN, Hands. Reine Rechtslehre. $2^{\mathrm{a}}$ ed. Aalen: Scientia, 1960.

. Vom Wesen und Wert der Demokratie (reimpresión de la edición de 1929). Aalen: Scientia, 1994.

LANGE, D. Citizenship education in Germany. In: The Making of Citizens in Europe. Bonn: Bundeszentrale für politische Bildung, 2008.

LINERA, Miguel Angel Presno et al. Teoría General de los Derechos Fundamentales en la Constitución Española de 1978. Madri: Tecnos, 2004.

LLAMAZARES; TEJÓN; CELADOR. Educación e Ideología. Madri: Dykinson, 2010.

LÓPEZ-MUÑIZ, J.L. Martínez. Siete Tesis sobre la Legalidad de la Educación Escolar Especializada por Razón de Sexo. Disponível em: http://www.diferenciada.org/ section. php?id=26\&id_element=172. Acessado em: 02-05-2011.

LUHMANN, Niklas. Das Erziehungssystem der Gesellschaft. Frankfurt a.M.: Suhrkamp, 2002.

MENÉNDEZ, I. Villaverde. Esbozo de una Teoría General de los Derechos Fundamentales. Revista Jurídica de Asturias. n² 22, 1998.

OTTO Y PARDO, I. de. Defensa de la Constitución y Partidos Politicos. Madri: CEPC, 1985.

RAMOS, B. Vila. La Formación del Ciudadano: un camino hacia la democracia participative. Comunicación y Hombre. Revista Interdisciplinar de Comunicación y Humanidades. $n^{\circ}$ 4, 2008.

SALEMA, M.H. Citizenship Education in Portugal. In: The Making of Citizens in Europe. Bonn: Bundeszentrale für politische Bildung, 2008.

SALGUERO, M. Socialización Política y Lealtad a la Constitución. Revista de Estudios Políticos, n 97, 1997.

SARDOĈ, M. Citizenship Education in Slovenia. In: The Making of Citizens in Europe. Bonn: Bundeszentrale für politische Bildung, 2008.

VILLAR, G. Cámara. Sobre el Concepto y los Fines de la Educación en la Constitución Española. In: Ministerio de Justicia (Edit.). X Jornadas de Estudios. Introducción a los Derechos Fundamentales, Vol. III. Madri: Dirección General del Servicio Jurídico del Estado, 1988.

YURACKO, K.A. Education Off the Grid: Constitutional Constrains on Homeschooling, California Law Review. Vol. 123, 2008. 